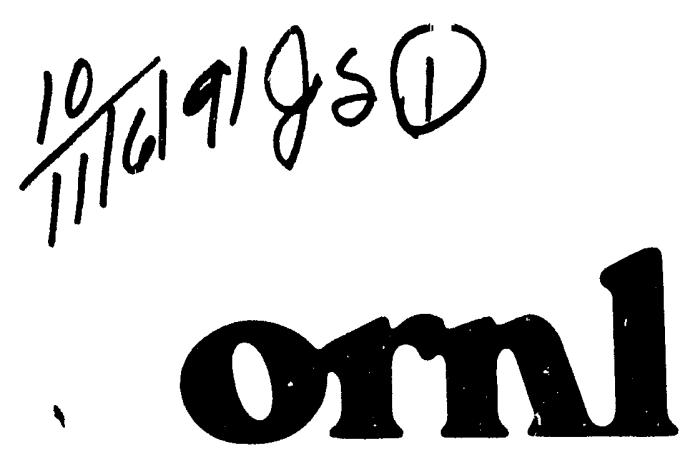

OAK RIDGE

NATIONAL

LABORATORY

MARTIN MARUETTA

\section{Corrosion of $\mathrm{SiC}$ and Oxide-Composite Ceramics by a Simulated Steam-Reformer Atmosphere}

\author{
J. I. Federer \\ H. E. Kim \\ A. J. Moorhead
}


This report has been reproduced directly from the best available copy.

Available to DOE and DOE contractrrs from the Office of Scientific and Technical Information, P.O. Box 62, Oak Ridge, TN 37831; prices available from (615) $576-8401$, FTS $626-8401$

Available to the public from the National Technical Information Service, U.S. Department of Commerce, 5285 Port Royal Rd., Springfield, VA 22161.

This report was prepared as an account of work sponsored by an agency of the United States Government. Neither the United States Government nor any agency thereof, nor any of their employees, makes any warranty, express or implied, or assumes any legal liability or responsibility for the accuracy, completeness, or usefulness of any information, apparatus, product, or process disclosed, or represents that its use would not infringe privately owned rights. Reference herein to any specific commercial product, process, or service by trade name, trademark, manufacturer, or otherwise. does not necessarily constitute or imply its endorsement. recommendation, or favoring by the United States Government or any agency thereof. The views and opinions of authors expressed herein do not necessarily state or reflect those of the United States Government or any agency thereot. 


\title{
CORROSION OF SiC AND OXIDE-COMPOSITE CERAMICS BY A SIMI_ATED STEAM-REFORMER ATMOSPHERE
}

\author{
J. I. Federer, H. E. Kim, and A. J. Moorhead
}

Date Published: Septemher 1991

NOTICE: This document contains information of a preliminary nature. It is subject to revision or correction and therefore does not represent a final report.

Prepared for the

U.S. Department of Energy

Assistant Secretary for Conservation and Renewable Energy

Office of Industrial Technologies

ED 0112000

Prepared by the

OAK RIDGE NATIONAL LABORATORY

Oak Ridge, Tennessee 37831-6285 managed by

MARTIN MARIETTA ENERGY SYSTEMS, INC.

for the

U.S. DEPARTMENT OF ENERGY

under contract DE-AC(05-84OR214()) 
TABLE OF CONTENTS

LIST OF FIGURES $\ldots \ldots \ldots \ldots \ldots \ldots \ldots \ldots \ldots$

LIST OF TABLES $\ldots \ldots \ldots \ldots \ldots \ldots \ldots \ldots \ldots \ldots \ldots \ldots \ldots$ vii

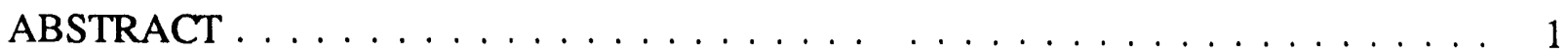

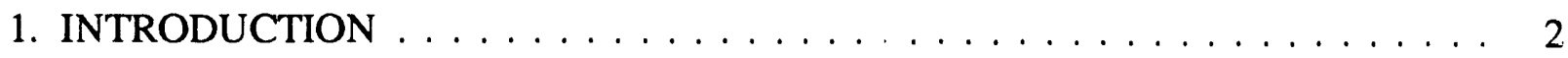

2. MATERIALS AND SPECIMENS $\ldots \ldots \ldots \ldots \ldots \ldots \ldots \ldots$

3. CORROSION CONDITIONS $\ldots \ldots \ldots \ldots \ldots \ldots \ldots \ldots$

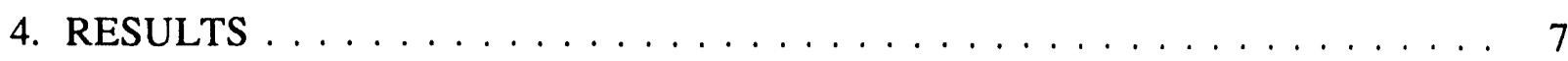

4.1 WEIGHT CHANGE $\ldots \ldots \ldots \ldots \ldots \ldots \ldots \ldots \ldots \ldots$

4.2 MICROSTRUCTURE AND IDENTIFICATION OF

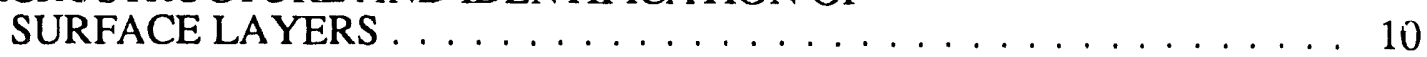

4.3 FLEXURE STRENGTH $\ldots \ldots \ldots \ldots \ldots \ldots \ldots \ldots \ldots \ldots \ldots$

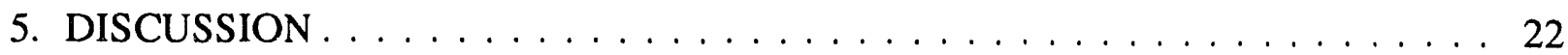

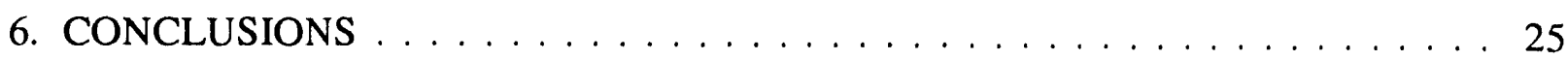

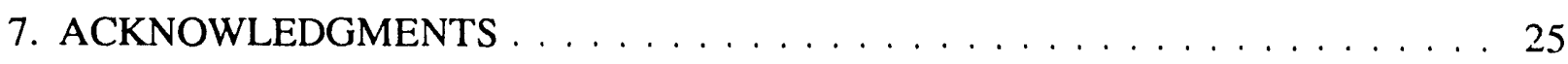

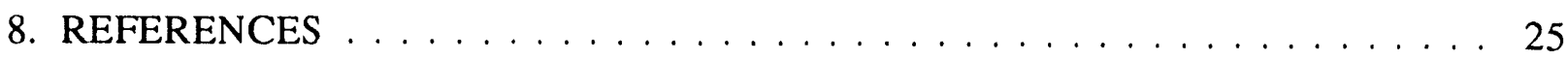




\section{LIST OF FIGURES}

Figure

Page

1 Schematic design of HiPHES tube within a tube steam

reformer . . . . . . . . . . . . . . . . . . .

$2 \quad$ Flexure bars after an exposure of $100 \mathrm{~h}$ to a simulated steam-reformer atmosphere at $1260^{\circ} \mathrm{C} \ldots \ldots \ldots 8$

3 Weight changes of materials exposed to the simulated steam-reformer atmosphere . . . . . . . . . . . . . . . . 9

$4 \quad$ Cumulative weight changes versus $v_{\text {time }} \ldots \ldots \ldots \ldots \ldots$

$5 \quad$ SA and RBSC before and after 500-h exposure to simulated steam-reformer atmosphere at $1260^{\circ} \mathrm{C}$

6 CHP and CSP before and after 500-h exposure to simulated steam-reformer atmosphere at $1260^{\circ} \mathrm{C} \ldots \ldots \ldots 13$

7 ST and SNSC before and after 500-h exposure to simulated steam-reformer atmosphere at $1260^{\circ} \mathrm{C} \ldots \ldots \ldots \ldots 14$

$8 \quad$ CAS and LAS before and after 500-h exposure to simulated steam-reformer atmosphere at $1260^{\circ} \mathrm{C} \ldots \ldots \ldots \ldots$

9 Scanning electron microscope photographs of fracture surfaces of materials corroded for $2000 \mathrm{~h}:(a) \mathrm{SA}$ and (b) $\operatorname{RBSC} 210$

10 Scanning electron microscope photographs of fracture surfaces of LAS: $(a)$ as polished, $(b)$ exposed $100 \mathrm{~h}$, (c) exposed $500 \mathrm{~h}$, and $(d)$ exposed $2000 \mathrm{~h} \ldots \ldots \ldots \ldots$

11 Scanning electron microscope photographs of the corroded surfaces of LAS: (a) as polished, $(b)$ exposed $100 \mathrm{~h}$, $(c)$ exposed $500 \mathrm{~h}$, and $(d)$ exposed $2000 \mathrm{~h}$.

12 Flexure strengths of materials exposed to a simulated steam-reformer atmosphere 


\section{LIST OF TABLES}

Table F'age

$1 \quad$ Materials in corrosion test $\ldots \ldots \ldots \ldots \ldots$

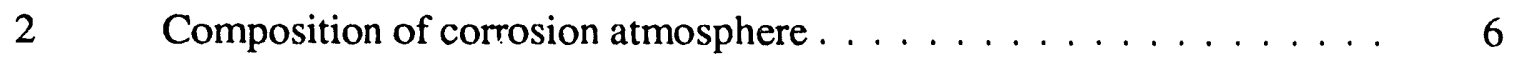

3 Summary of specimens used for corrosion exposure and flexure testing . . . . . . . . . . . . . . . . . 7

$4 \quad$ Flexure strengths and standard deviations of materials ......................... 20 


\title{
CORROSION OF SiC AND OXIDE-COMPOSITE CERAMICS BY A SIMULATED STEAM-REFORMER ATMOSPHERE*
}

\author{
J. I. Federer, H. E. Kim, and A. J. Moorhead
}

\begin{abstract}
To achieve higher piocess efficiency by using pressurized reactants and/or heat transfer fluids, the U.S. Department of Energy is promoting development of high-pressure heat exchanger systems under cost-sharing agreements with industrial contractors. Toward this end, Stone and Webster Engineering Corporation (Boston, MA) proposes to use a pressurized heat exchanger/reactor for steam-reforming of natural gas. The proposed steam reformer would contain more than 600 tubes. Because the combination of high temperature and pressure differential of $12.7 \mathrm{~kg} / \mathrm{cm}^{2}(180 \mathrm{psig})$ across the tube wall is too severe for metallic tubes, ceramic materials are being considered for reformer tubes. Their use is expected to increase the efficiency of steam reformers by about $19 \%$.

At Oak Ridge National Laboratory, four $\mathrm{SiC}$ ceramics, a $\mathrm{SiC}-\mathrm{TiB}_{2}$ composite, a $\mathrm{Si}_{3} \mathrm{~N}_{4}$-bonded $\mathrm{SiC}$ ceramic, and two alumina-matrix composites were selected as candidate materials for heat exchanger/steam-reformer tubes. These commercially available materials were exposed to a simulated steamreformer atmosphere for up to $2000 \mathrm{~h}$ at $1260^{\circ} \mathrm{C}$ to assess their corrosion behavior and the effect of the exposure on their flexure strength (in air) at 20 and $1260^{\circ} \mathrm{C}$. The approximiate partial pressures (in atmosphere) of the constituents of the gas mixture at $1 \mathrm{~atm}$ total pressure were $0.54 \mathrm{H}_{2}, 0.13$ $\mathrm{CO}, 0.03 \mathrm{CO}_{2}, 0.004 \mathrm{CH}_{4}$, and $0.30 \mathrm{H}_{2} \mathrm{O}$. All but one material had net weight gains during the exposure test. One composite material initially lost weight, then gained weight with increasing time, and probably would have exhibited a net weight gain for longer exposure times. The flexure strengths of the $\mathrm{SiC}$ and $\mathrm{Si}_{3} \mathrm{~N}_{4}$ ceramics and the $\mathrm{SiC}-\mathrm{TiB}_{2}$ composite at 20 and $1260^{\circ} \mathrm{C}$ were not changed significantly by corrosion. In fact, the strengths at $1260^{\circ} \mathrm{C}$ of the $\mathrm{SiC}$ ceramics exposed for $2000 \mathrm{~h}$ were slightly higher after exposure. The strengths of the alumina-matrix composites were decreased by corrosion; however, the strength of one of these (reinforced with $\mathrm{SiC}$ whiskers) was still higher than that of any other material after $500 \mathrm{~h}$. The other alumina composite (containing SiC particles) exhibited the largest strength decrease of any material. The strength retention of the $\mathrm{SiC}$ ceramics and the $\mathrm{SiC}^{-\mathrm{TiB}_{2}}$ composite and the strength loss of the composites were associated with surface layers caused by corrosion. The SiC ceramics formed silica layers with smooth exterior surfaces that caused retention or increase of strength. The alumina composites, however, formed rough crystalline layers containing numerous stress concentration points that apparently decreased the strength of the material.
\end{abstract}

${ }^{*}$ Research sponsored by the U.S. Department of Energy, Assistant Secretary for Conservation and Renewable Energy, Office of Industrial Technologies, Industrial Energy Efficiency Division, under contract DE-AC05-84OR21400 with Martin Marietta Energy Systems, Inc. 


\section{INTRODUCTION}

Development of high-pressure heat exchanger systems (HiPHES) is being promoted by the U.S. Department of Energy under cost-sharing agreements with industrial contractors. ${ }^{1-3}$ The goal of these systems is to achieve higher process efficiency by using pressurized reactants and/or heat transfer fluids. ${ }^{1-5}$ For example, Stone and Webster Engineering Corporation (SWEC), Boston, MA, proposes to use a pressurized heat exchanger/reactor for steamreforming of natural gas. ${ }^{1,2}$ In this process (see Fig. 1), steam and natural gas are reacted at elevated temperatures and pressures in catalyst-filled ceramic tubes of the reformer to form synthesis gas compused mainly of $\mathrm{H}_{2}, \mathrm{CO}$, and residual $\mathrm{H}_{2} \mathrm{O}$ that, subsequently, can be converted to methanol. An integral gas turbine, driven by the methanol plant-generated fuel gas and methane, supplies pressurized air to the external combustor of the reformer, which produces a flue gas temperature of $1260^{\circ} \mathrm{C}$. The resulting pressure of the combustion products of about $8.4 \mathrm{~kg} / \mathrm{cm}^{2}(120 \mathrm{psia})$ increases the efficiency of heat transfer to the reformer tubes. Efficiency of conversion of methane to synthesis gas inside the tubes is favored by higher reaction temperature and lower pressure; however, because the synthesis gas must be compressed in the subsequent methanol conversion process, the reaction pressure in the reformer tubes is selected to optimize the overall process. Thus, the reforming conditions in SWEC's design involve a reaction temperature of about $1040^{\circ} \mathrm{C}$ and a pressure of $21.1 \mathrm{~kg} / \mathrm{cm}^{2}$ $(300 \mathrm{psia})$. The reaction temperature is supplied as the aforementioned pressurized flue gases (at 1260$)^{\circ} \mathrm{C}$ ) pass counter-current to the reformer/rea tor tubes. The combination of high temperature and pressure differential of $12.7 \mathrm{~kg} / \mathrm{cm}^{2}(180 \mathrm{psia})$ across the tube wall is too severe for metallic tubes, which are typically limited to a lower temperature. Ceramic materials, therefore, are being considered for reformer reaction tubes in order to sustain the higher flue gas temperature of $: 261)^{\circ} \mathrm{C}$ and a higher process operating temperature inside the tubes. Their use is expected to increase the efficiency of steam reformers by about $19 \%, 1,2$

Silicon carbide-based ceramics have physical and mechanical properties that recommend theis use for reformer tubes. These properties include high strength and thermal conductivity, low coefficient of thermal expansion, and high resistance to oxidation (in air) and thermal slock. Toughened-alumina ceramics are also candidate materials. Monolithic alumina is strong and resistant to oxidation and corrosion, but unless toughened with whiskers, particles, or filaments, is too susceptible to damage by creep or thermal shock for this type of application.

The proposed steam reformer will contain more than $6(0)$ tubes measuring about $8.9 \mathrm{~cm}$ (3.5 in.) OD by about $12.1 \mathrm{~m}(40 \mathrm{ft}$ ) in length. Because reformer tubes will be subjected to high-pressure, steam-containing atmospheres at high temperatures, a corrosion study of 
ORNL DWG 91-9638

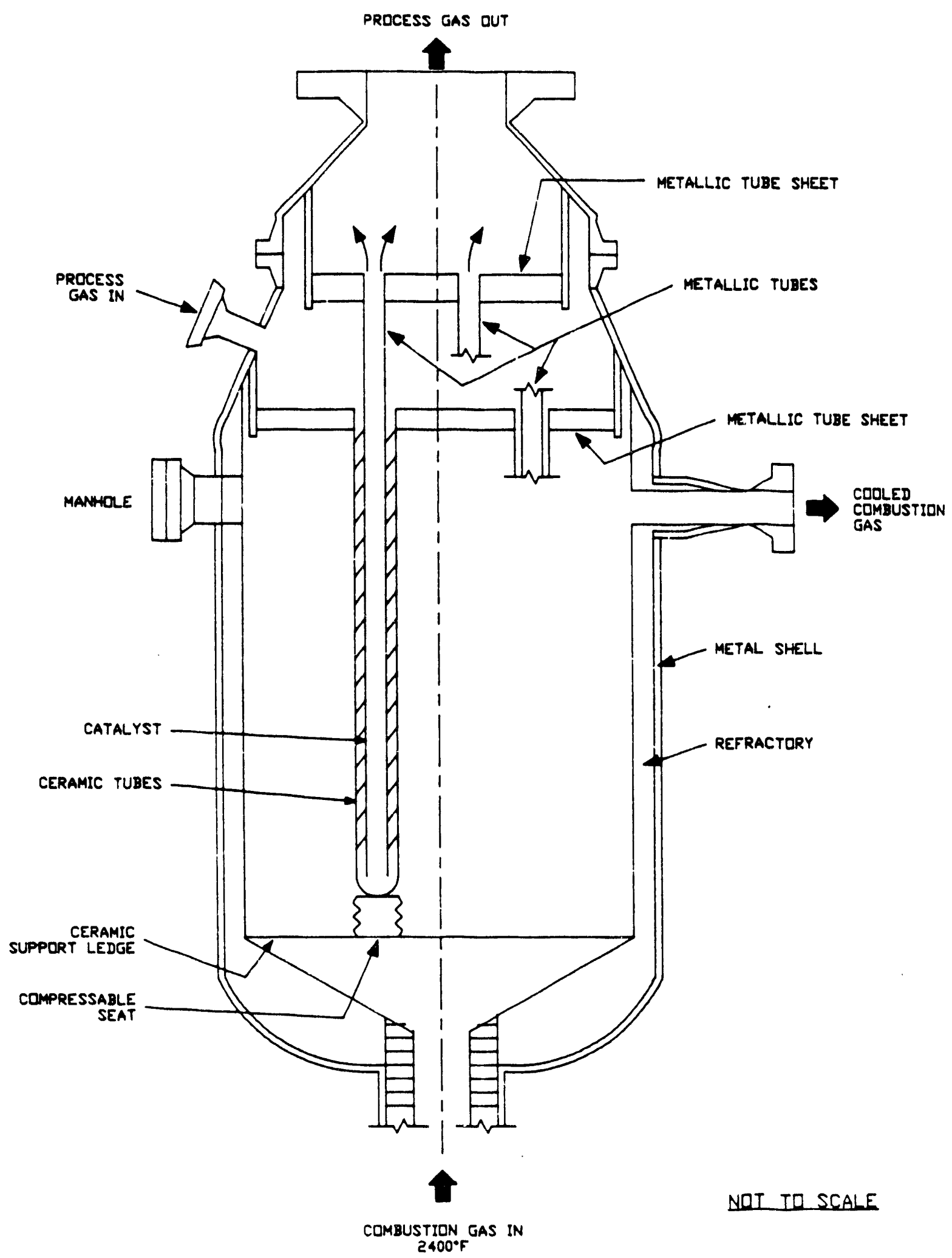

Fig. 1. Schematic design of HiPHES tube within a tube steam reformer. 
candidate materials was conducted. Previous studies have indicated that oxidation of $\mathrm{SiC}$ is accelerated by steam in the atmosphere. The results of some of these investigations will be discussed in the following sections. In this study, the high-temperature corrosion behavior of several candidate materials in a simulated steam-reformer atmosphere was determined.

Changes in weight, flexural strength, and microstructure were the main indicators of the effects of corrosion. To represent a worst-case situation in case of loss of temperature control, the conditions of the corrosion test were deliberately chosen to be more severe with respect to temperature than the actual application. The anticipated flue gas temperature of $1260^{\circ} \mathrm{C}$ was used even though the anticipated inner wall temperature is $1040^{\circ} \mathrm{C}$. The pressure, however, was only $1.03 \mathrm{~kg} / \mathrm{cm}^{2}(14.7 \mathrm{psia})$ instead of the anticipated value of $21.1 \mathrm{~kg} / \mathrm{cm}^{2}$ (300 psia).

\section{MATERIALS AND SPECIMENS}

Initially, eight materials selected by SWEC were corrosion tested (Table 1). These included four $\mathrm{SiC}$ ceramics, a toughened $\mathrm{SiC}-\mathrm{TiB}_{2}$ ceramic composite, a $\mathrm{Si}_{3} \mathrm{~N}_{4}$-bonded $\mathrm{SiC}$, and two alumina-matrix composites. Hexoloy $\mathrm{SA}^{*}$ is pressureless, sintered, alpha $\mathrm{SiC}$ that is approximately $99 \%$ pure and has a density of about $3.10 \mathrm{~g} / \mathrm{cm}^{3}$ (theoretical density of

Table 1. Materials in corrosion test

\begin{tabular}{lcl}
\hline \multicolumn{1}{c}{ Name } & $\begin{array}{c}\text { Designation } \\
\text { this study }\end{array}$ & \multicolumn{1}{c}{ Manufacturer } \\
\hline Hexoloy SA & SA & The Carborundum Company \\
Hexoloy ST & ST & The Carborundum Company \\
Crystar high-purity SiC & CHP & Norton Company \\
$\begin{array}{l}\text { Crystar standard-purity SiC } \\
\text { Reaction-bonded SiC }\end{array}$ & CSP & Norton Company \\
$\begin{array}{l}\text { Nitride-bonded SiC } \\
\text { SiC whisker-toughened } \\
\text { aluminum Oxide }\end{array}$ & RBSC & Coors Ceramics Company \\
$\begin{array}{l}\text { SiC/alumina-matrix } \\
\text { composite }\end{array}$ & SNSC & Ferro Corporation \\
\hline
\end{tabular}

${ }^{*}$ The Carborundum Company, Niagara Falls, New York. 
$3.210 \mathrm{~g} / \mathrm{cm}^{3}$ ). Hexoloy $\mathrm{ST}^{*}$ is a composite consisting of an alpha $\mathrm{SiC}$ matrix containing $20 \mathrm{wt} \% \mathrm{TiB}_{2}$ particles that, compared with Hexoloy SA, improve the machinability and room-temperature fracture toughness. The two Crystar materials ${ }^{\dagger}$ (i.e., CSP and CHP) are similar in that both consist of interpenetrating matrices of $\mathrm{SiC}$ and approximately $15 \mathrm{vol} \% \mathrm{Si}$. The CHP material contained a lower Fe content than CSP; otherwise, their compositions were similar. RBSC210 $0^{\ddagger}$ is a reaction-bonded material containing 10 to $15 \mathrm{vol} \% \mathrm{Si}$ in a SiC matrix. NiBond** (designated SNSC in this work) consists of $\mathrm{SiC}$ grains bonded by a $\mathrm{Si}_{3} \mathrm{~N}_{4}$ matrix. The two composites (designated $\mathrm{CAS}^{\dagger \dagger}$ and $\mathrm{LAS}^{\ddagger \ddagger}$ in this work) are both toughened ceramics having aluminum oxide matrices. CAS is reinforced with approximately $25 \mathrm{vol} \% \mathrm{SiC}$ whiskers, while LAS is toughened with approximately $55 \mathrm{vol} \% \mathrm{SiC}$ particles. LAS also contains $\mathrm{Al}$ metal, a residue from the manufacturing process.

Flexure bars measuring approximately $2.5 \times 3.5 \times 25 \mathrm{~mm}$ were prepared by Oak Ridge National Laboratory (ORNL) from sheet material supplied by SWEC. Specimens were ground to thickness with diamond-impregnated wheels and sawed to width and length with diamondimpregnated circular blades. One major surface was polished scratch-free with $3-\mu \mathrm{m}$ grit diamond paste on a polishing wheel. The long edges of the polished surface were slightly beveled to remove chips and other flaws visible at $10 \times$ magnification. These small, nonstandard flexure bars were dictated by the size of the starting stock and by the desire to expose a large number of specimens simultaneously to the corrosive atmosphere in a small laboratory furnace.

\section{CORROSION CONDITIONS}

Initially, 16 specimens of each material except SNSC (i.e., 11 specimens) were exposed to a simulated steam-reformer atmosphere (synthesis gas) at $1260^{\circ} \mathrm{C}$ and 14.7 psia pressure. The atmosphere consisted of $\mathrm{H}_{2}, \mathrm{CO}, \mathrm{CO}_{2}, \mathrm{CH}_{4}$, and $\mathrm{H}_{2} \mathrm{O}$. The composition of the gas mixture corresponded to the equilibrium mixture that would be obtained at $1040^{\circ} \mathrm{C}$ and 300 psia, while the temperature of 1260$)^{\circ} \mathrm{C}$ represented the anticipated maximum flue gas temperature at the bottom of the reformer tubes. The four gases were metered at room temperature with

\footnotetext{
${ }^{*}$ The Carborundum Company, Niagara Falls, New York.

${ }^{\dagger}$ Norton Company, Worcestshire, Massachusetts.

$\$, \dagger^{\dagger}$ Coors Ceramics Company, Golden, Colorado.

${ }^{* *}$ Ferro Corporation, Buffalo, New York.

$\sharp$ DuPont/Lanxide Corporation, Newark, Delaware.
} 
conventional tube and float flow meters into a common line leading to a heated stainless steel chamber in which water (metered with a peristaltic pump) was vaporized at about $250^{\circ} \mathrm{C}$. The mixture of gases and $\mathrm{H}_{2} \mathrm{O}$ vapor with the partial pressures (calculated from flow rates) shown in Table 2 then passed over the specimens located in a $60-\mathrm{mm}$-ID by $1.5-\mathrm{m}$-long mullite tube in a resistance-heated furnace. The specimens rested on $\mathrm{Al}_{2} \mathrm{O}_{3}$ rails on an $\mathrm{Al}_{2} \mathrm{O}_{3}$ setter at the midpoint of the furnace where the temperature was 1255 to $1260^{\circ} \mathrm{C}$.

Table 2. Composition of corrosion atmosphere

\begin{tabular}{crrrr}
\hline & \multicolumn{3}{c}{ Flow rate } & \\
\cline { 2 - 5 } Component & $\begin{array}{r}\mathrm{cc} / \mathrm{min} \\
\text { at } 20^{\circ} \mathrm{C}\end{array}$ & $\mathrm{g} / \mathrm{min}$ & mole \% & $\begin{array}{c}\text { Partial } \\
\text { pressure } \\
\text { (atm) }\end{array}$ \\
\hline & 1280 & 0.106 & 53.9 & 0.539 \\
$\mathrm{H}_{2}$ & 305 & 0.354 & 13.2 & 0.132 \\
$\mathrm{CO}$ & 75 & 0.137 & 3.0 & 0.030 \\
$\mathrm{CO}_{2}$ & 10 & 0.007 & 0.4 & 0.004 \\
$\mathrm{CH}_{4}$ & & $0.53^{*}$ & 29.5 & 0.295 \\
$\mathrm{H}_{2} \mathrm{O}$ & & & & \\
\hline
\end{tabular}

*Metered as a liquid into a vaporizer.

The number of specimens corrosion tested and flexure tested is summarized in Table 3. Specimens of the original eight materials were exposed for $100 \mathrm{~h}$; weight changes were determined and half of the specimens were subjected to flexure testing. The remaining specimens were exposed for a total of $500 \mathrm{~h}$ then treated in the same manner. Based upon these results and further discussions with the manufacturers concerning the fabricability of materials in the required tubular shapes and sizes, four materials (ST, CHP, SNSC, and CAS) were eliminated by SWEC from further consideration for this part of their HiPHES project. Subsequently, 20 new specimens of the remaining four materials were exposed for $2000 \mathrm{~h}$ and then weighed and tested in flexure. In addition, polished cross sections of typical specimens were examined by optical microscopy, and both exposed and fracture surfaces were examined by scanning electron microscopy ${ }^{*}$ and $X$-ray diffraction.

\footnotetext{
*S-8()0, Hitachi, Ltd., Tokyo, Japan.
} 
Table 3. Summary of specimens used for corrosion exposure and flexure testing

\begin{tabular}{lccc}
\hline & \multicolumn{3}{c}{ Number of specimens exposed/flexure tested for the exposure times (h) } \\
\cline { 2 - 2 } Material & 100 & 500 & 2000 \\
\hline SA & $16 / 8$ & $8 / 8$ & $20 / 16$ \\
CSP & $16 / 8$ & $8 / 8$ & $20 / 16$ \\
RBSC & $16 / 8$ & $8 / 8$ & $201 / 6$ \\
LAS & $16 / 8$ & $8 / 8$ & $20 / 16$ \\
CHP & $16 / 8$ & $8 / 8$ & 0 \\
ST & $16 / 8$ & $8 / 8$ & 0 \\
SNSC & $11 / 6$ & $5 / 5$ & 0 \\
CAS & $16 / 8$ & $8 / 8$ & 0 \\
\hline
\end{tabular}

\section{RESULTS}

\subsection{WEIGHT CHANGE}

Figure 2 shows specimens of the original eight materials still resting on the $\mathrm{Al}_{2} \mathrm{O}_{3}$ rails after an exposure of $100 \mathrm{~h}$. A glassy, transparent, or white film had formed on the Si-based specimens, while the original polished surfaces of the two alumina-based composite materials had become dull. A white material, identified as $\mathrm{Al}_{2} \mathrm{O}_{3}$ by $\mathrm{X}$-ray diffraction, had formed on surfaces of the LAS specimens and some particles had migrated to other specimens (Fig. 2). Evidently, residual Al had exuded to the surface and oxidized. Most of this material was easily removed with a wire brush before weighing. The appearance of the four materials exposed for $2000 \mathrm{~h}$ was similar to that after exposure for $100 \mathrm{~h}$.

All materials had net weight gains during exposure except the LAS (Fig. 3). The bars for each material exposed for $100 \mathrm{~h}$ represent an average weight of 16 specimens (except only 11 for SNSC); those exposed for $500 \mathrm{~h}$, an average weight of 8 specimens (except only 5 for SNSC); and those exposed for $2000 \mathrm{~h}$, an average weight of 20 specimens. Two of the SiC ceramics (SA and RBSC) gained weight between 500 and $2000 \mathrm{~h}$, while the other (CSP) did not change significantly between 100 and $2000 \mathrm{~h}$. In the case of the SiC ceramics, each incremental weight gain of $0.1 \%$ is approximately equivalent to a calculated uniform surface recession (by oxidation) of only about $1 \mu \mathrm{m}$. Each material had an oxide layer on the surface. In contrast, the LAS material lost weight, but the magnitude of the net loss decreased during 


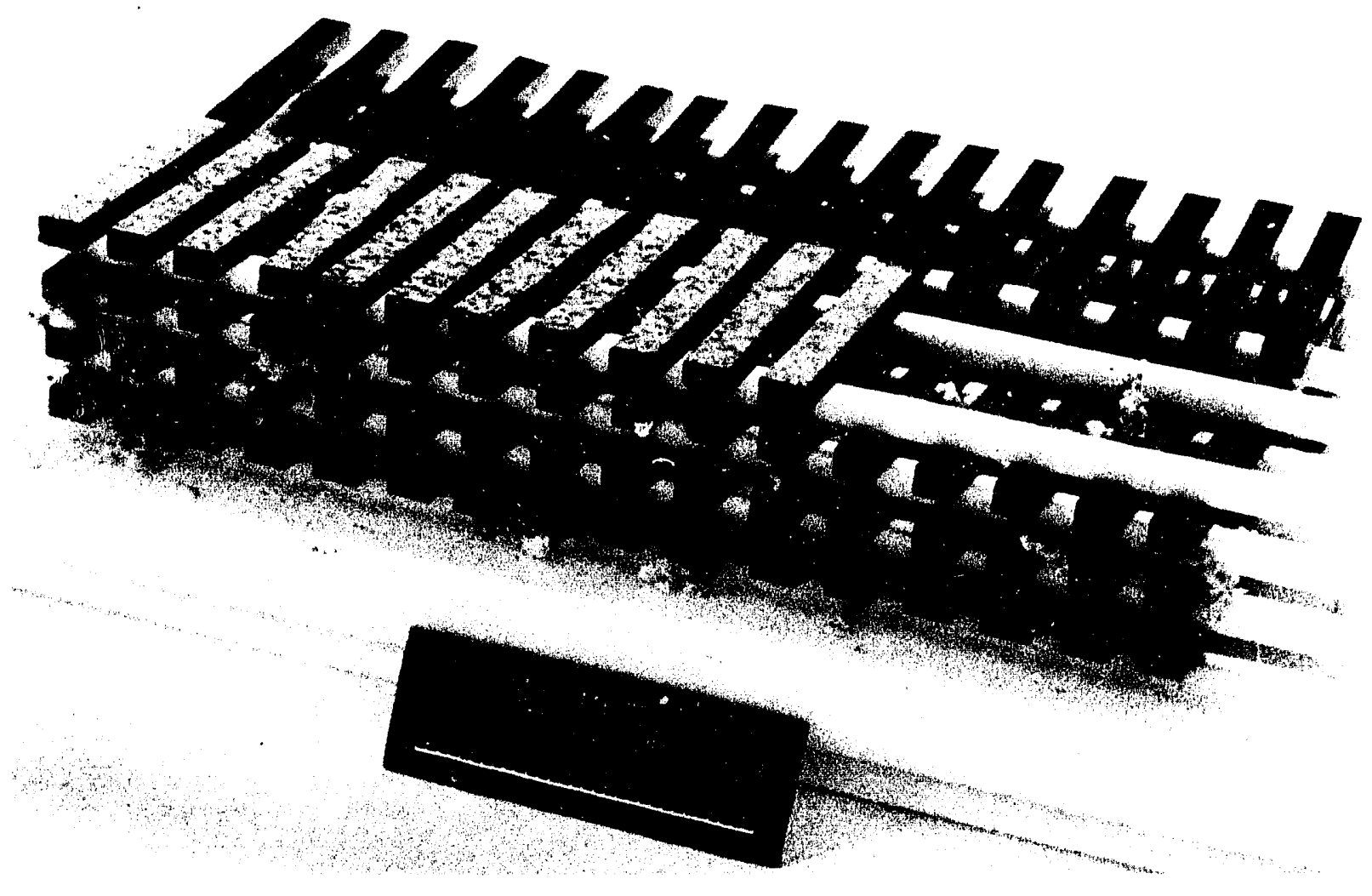

Fig. 2. Flexure bars after an exposure of $100 \mathrm{~h}$ to a simulated steam-reformer atmosph sre at $1260^{\circ} \mathrm{C}$. 


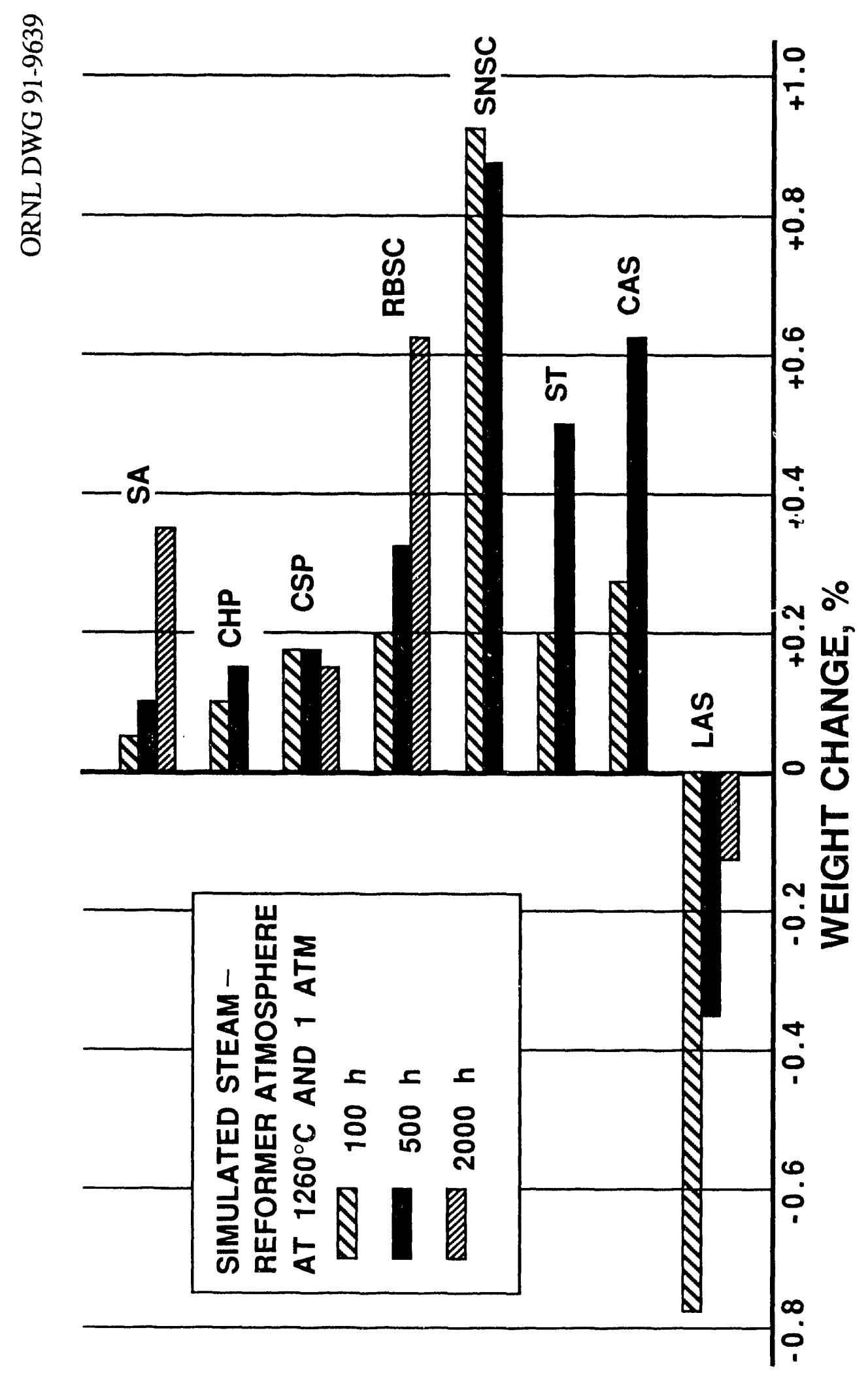


successive exposure periods. The initial high weight loss associated with loss of $\mathrm{Al}$ was followed by oxidation, which eventually would have probably caused a net weight gain. During the 500-h exposure, CAS gained more weight than most of the SiC ceramics. This behavior was attributed to the oxidation of the $\mathrm{SiC}$ whiskers in the $\mathrm{Al}_{2} \mathrm{O}_{3}$ matrix and the formation of new phases (discussed in Subsection 4.2).

Cumulative weight changes per unit area are plotted versus the square root of exposure time in Fig. 4 to determine if the data conform to the parabolic expression $\mathrm{x}^{2}=\mathrm{kt}$, where $\mathrm{x}$ is the weight of oxidation product, $\mathrm{k}$ is a constant, and $\mathrm{t}$ is oxidation time. ${ }^{6}$ The plot for $\mathrm{CHP}$ is linear, and the plots for SNSC and RBSC are approximately linear; this indicates that oxidation of these materials was controlled by diffusion of (probably) $\mathrm{H}_{2} \mathrm{O}$ through the oxide layer to the $\mathrm{SiC}$. The corrosion of the CSP was linear during the first $500 \mathrm{~h}$, but oxidation occurred more slowly in the interval of 500 to $2000 \mathrm{~h}$. SA, ST, and CAS each exhibited "slow" kinetics during the first $100 \mathrm{~h}$, but the plot for SA is approximately linear for the period of 100 to $2000 \mathrm{~h}$. The LAS plot exhibits the results of weight loss caused by loss of $\mathrm{Al}$ and simultaneous oxidation. A linear weight change might eventually occur during a longer exposure than $2000 \mathrm{~h}$.

\subsection{MICROSTRUCTURE AND IDENTIFICATION OF SURFACE LA YERS}

Optical photomicrographs of polished cross sections of specimens before and after the 500 -h exposure to the simulated steam-reformer atmosphere at $1260^{\circ} \mathrm{C}$ are shown in Figs. 5 through 8. Each material exhibits a reaction layer on the surface that varied in thickness from about $10 \mu \mathrm{m}$ for the SiC ceramics to about $50 \mu \mathrm{m}$ for SNSC, CAS, and LAS. The reaction layer on the SiC ceramics (Figs. 5 and 6) appears to be a simple oxide. The Si phase in these materials was not attacked significantly faster than the $\mathrm{SiC}$ phase. Figure 7 indicates that the $\mathrm{TiB}_{2}$ particles in ST were attacked preferentially to the $\mathrm{SiC}$ matrix and that the $\mathrm{Si}_{3} \mathrm{~N}_{4}$ matrix was attacked preferentially to the SiC particles in SNSC. The reaction layers on both ST and SNSC appear to contain new phases that might have precipitated during cooling. The two oxide composites (i.e., CAS and LAS) in Fig. 8 exhibit relatively thick reaction layers containing apparent voids and new phases. The CAS material, as previously mentioned, consists of $\mathrm{SiC}$ whiskers in an $\mathrm{Al}_{2} \mathrm{O}_{3}$ matrix, while LAS consists of $\mathrm{SiC}$ particles and residual $\mathrm{Al}$ in an $\mathrm{Al}_{2} \mathrm{O}_{3}$ matrix. Aluminum, the phase having the lightest shading in the LAS material, is still present after $20(0) \mathrm{h}$. Pores in the $\mathrm{Al}$ indicate shrinkage on cooling from the molten state or loss of material by evaporation. 
ORNL DWG 91-9640
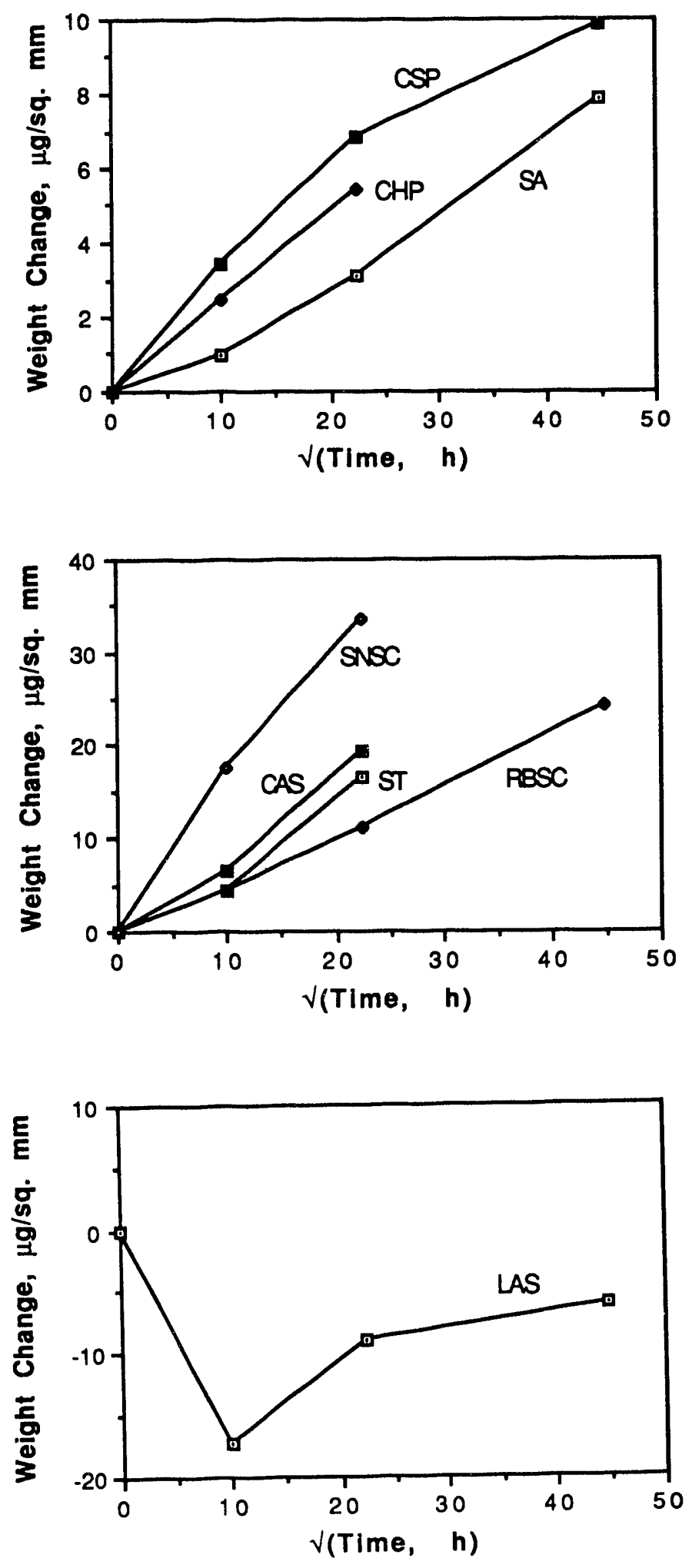

Fig. 4. Cumulative weight changes versus $\sqrt{ }$ time. 


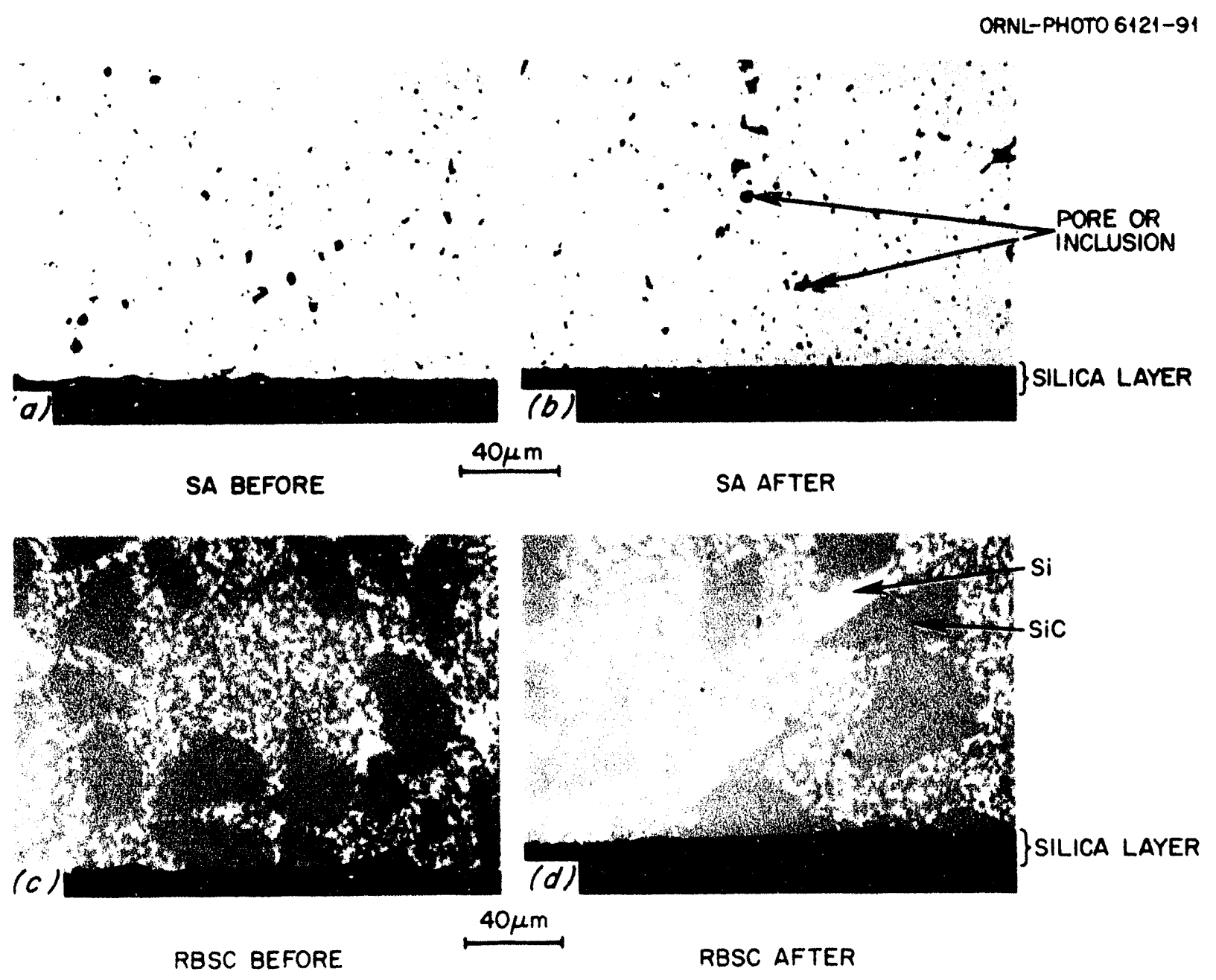

Fig. 5. SA and RBSC before and after 500-h exposure to simulated steam-reformer atmosphere at $1260^{\circ} \mathrm{C}$. 
ORNL-PHOTO 6120-91
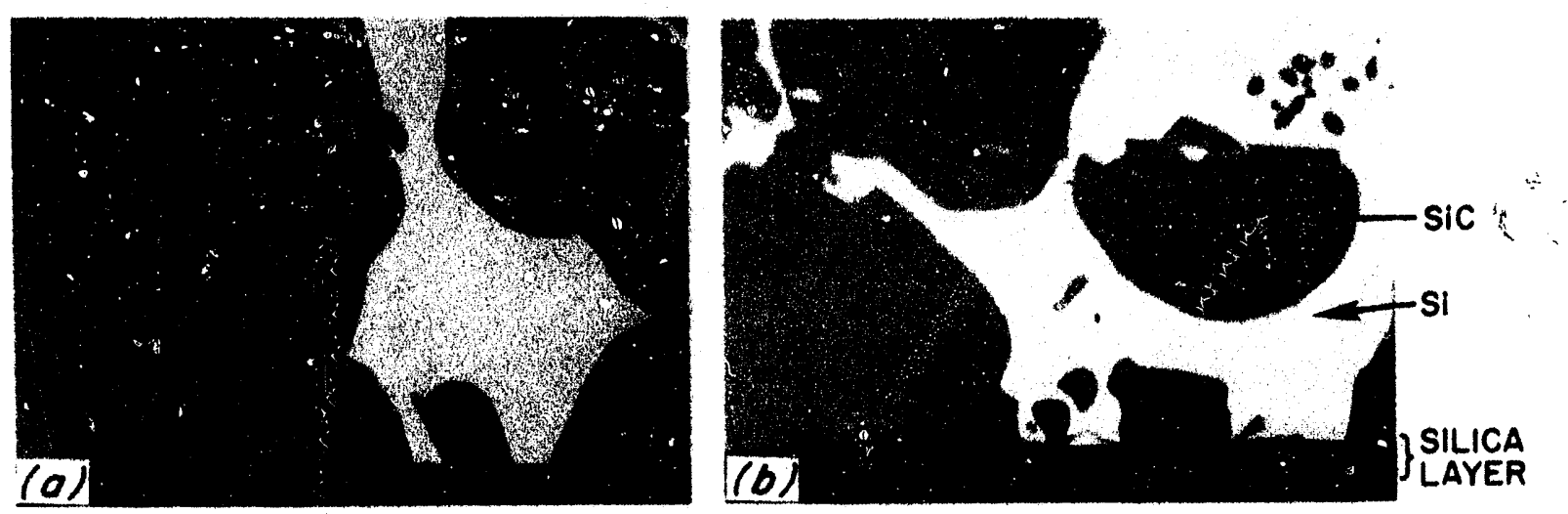

CHP BEFORE

CHP AFTER

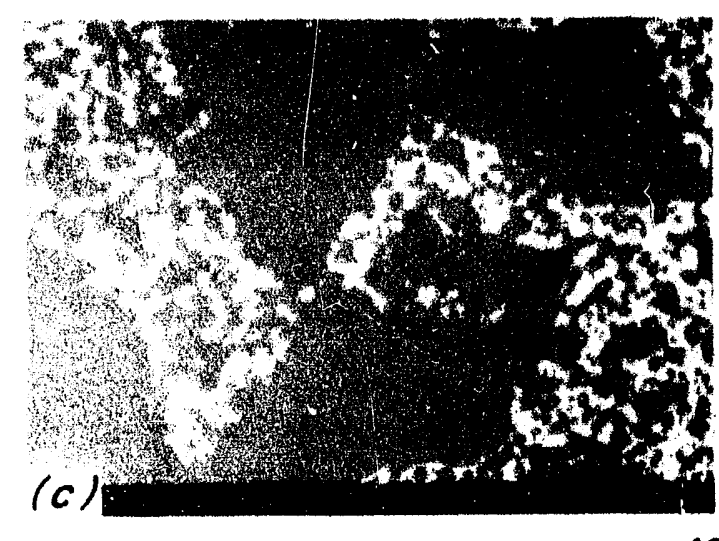

CSP BEFORE
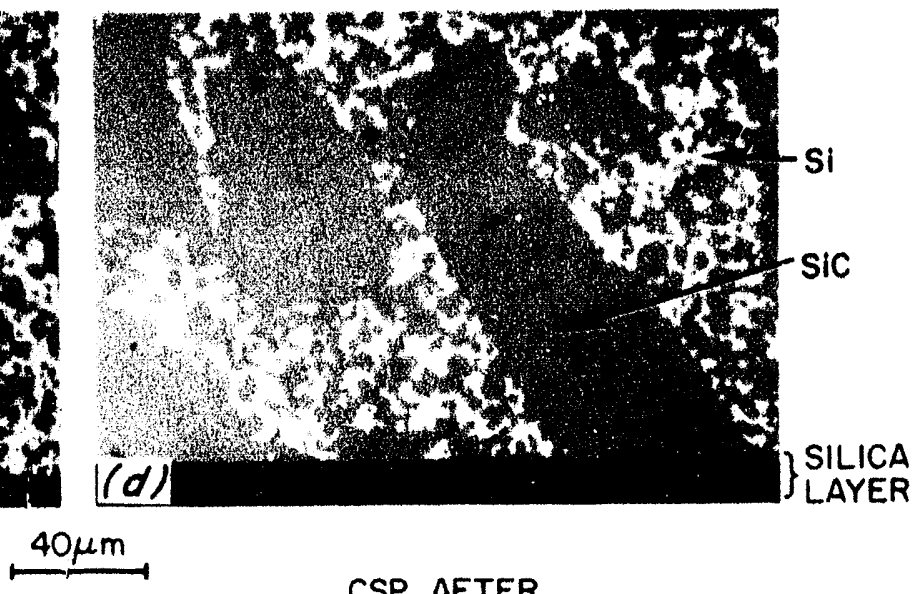

CSP AFTER

Fig. 6. CHP and CSP before and after 50(-h exposure to simulated steam-reformer atmosphere at $1260^{\circ} \mathrm{C}$. 
ORNL-PHOTO 6122-91
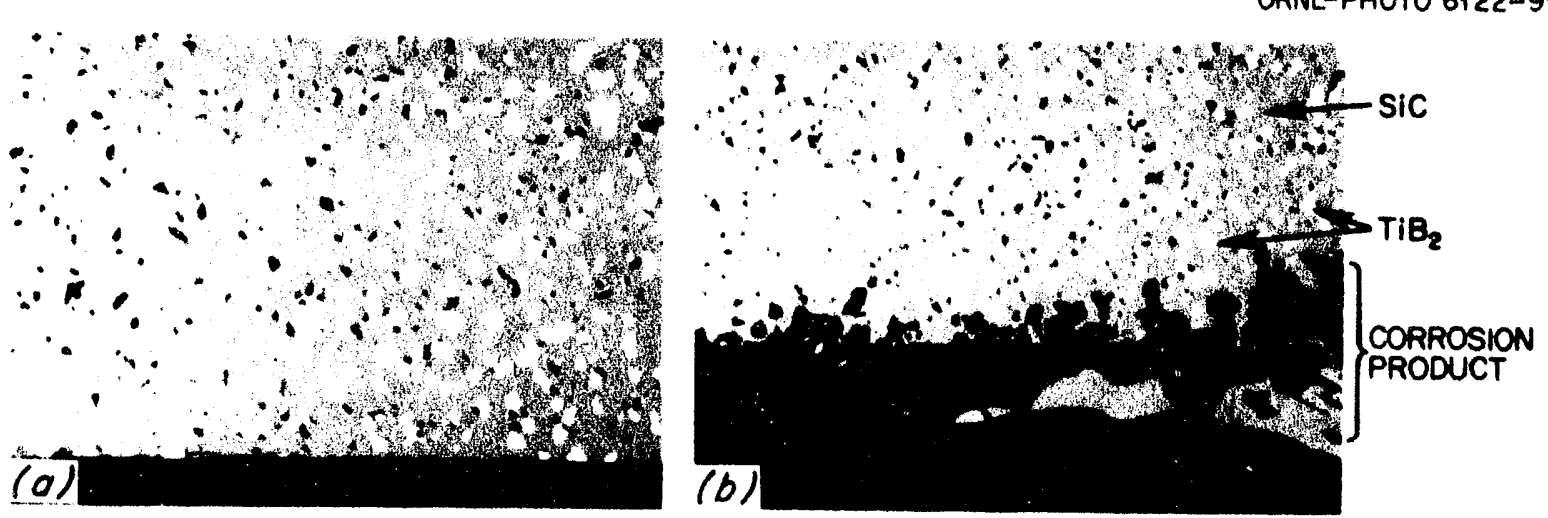

ST BEFORE

$\stackrel{40 \mu \mathrm{m}}{2}$

ST AFTER

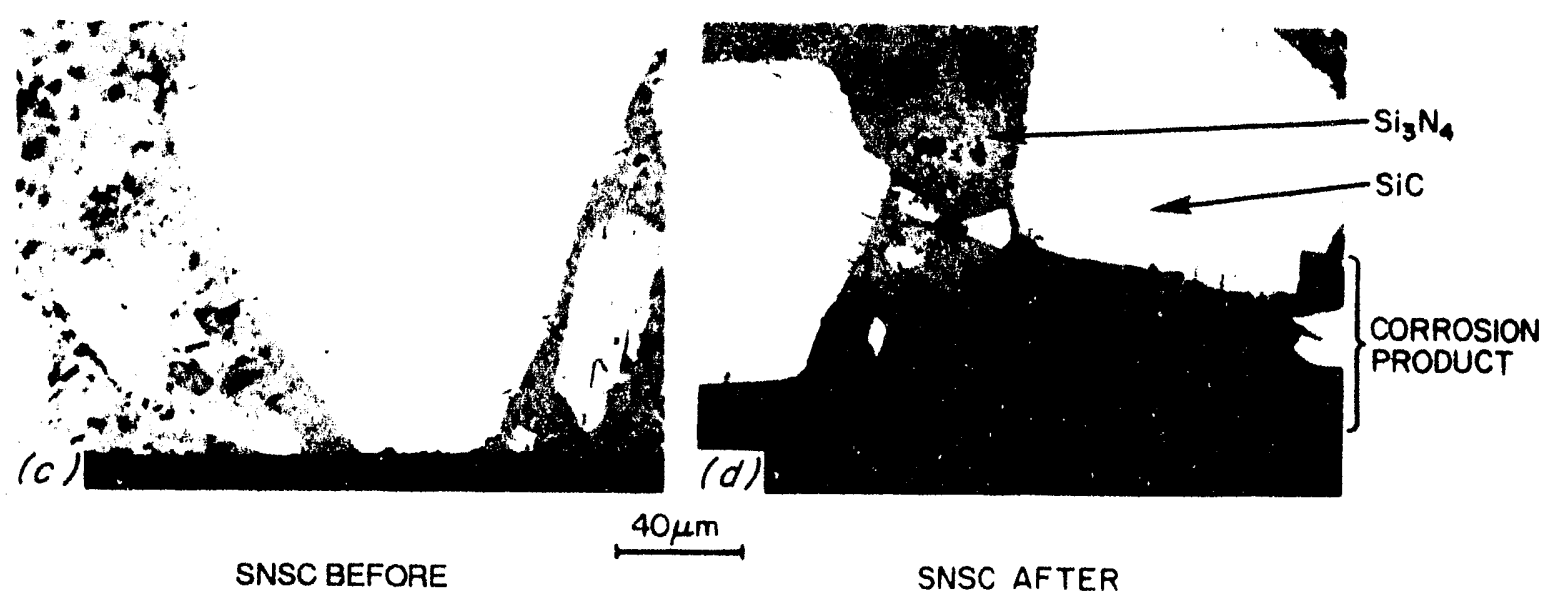

Fig. 7. ST and SNSC before and after 50)-h exposure to simulated steam-reformer atmosphere at $1260^{\circ} \mathrm{C}$. 
ORNL-PHOTO 6118-91
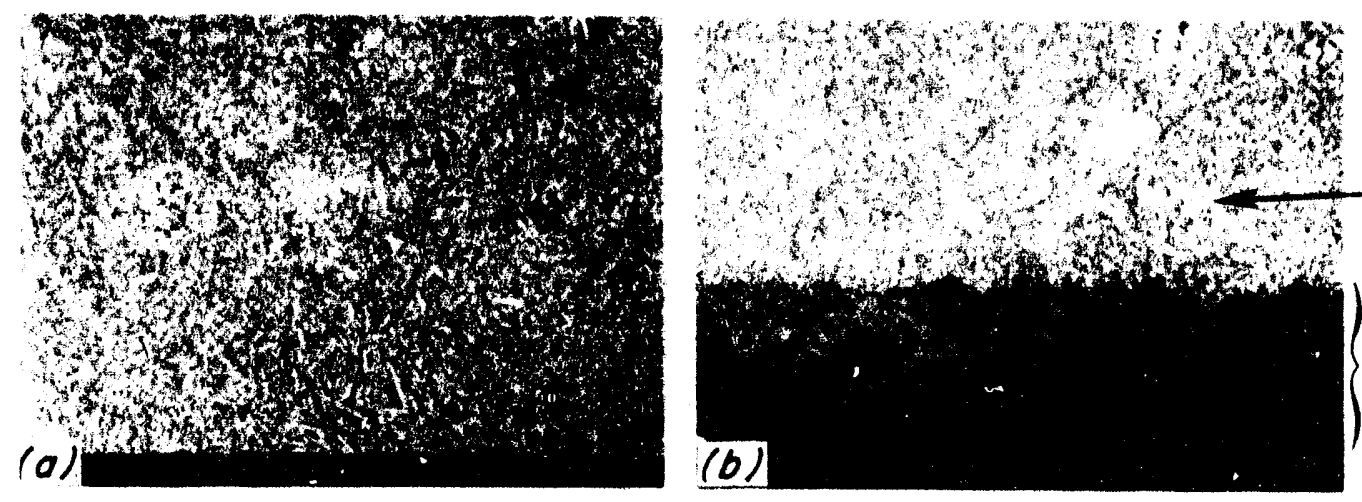

SIC WHISKERS IN ALUMINA MATRIX CORROSION PRODUCT

CAS BEFORE

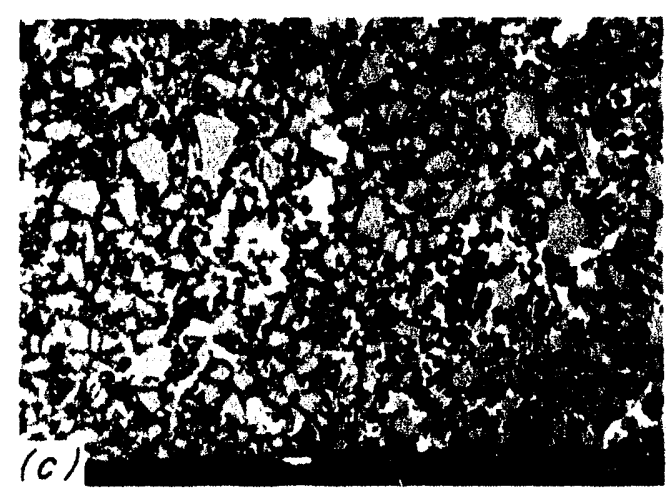

$40 \mu \mathrm{m}$

LAS BEFORE

LAS AFTER

CAS AFTER

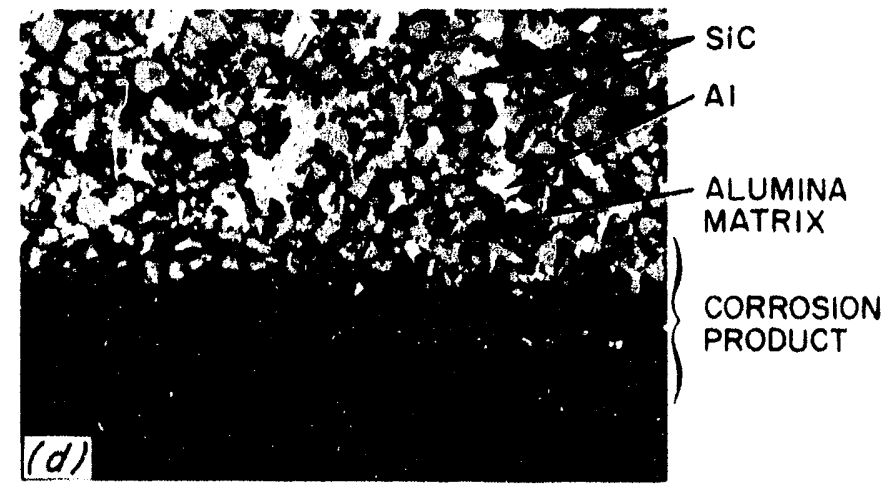

Fig. 8. CAS and LAS before and after 500-h exposure to simulated steam-reformer atmosphere at $1260^{\circ} \mathrm{C}$. 
After 2000-h exposure, the three SiC ceramics (i.e., SA, CSP, and RBSC) had corrosionproduced layers with thicknesses in the range of 20 to $25 \mu \mathrm{m}$, while the layer on the LAS was about $80-\mu \mathrm{m}$ thick. Using layer thicknesses after $500 \mathrm{~h}$ to aid in projection, the estimated layer thickness on SA, CSP, and RBSC would be $2.3 \mathrm{~mm}(0.09 \mathrm{in}$.) after $10,000 \mathrm{~h}$. Similarly, the estimated layer thickness on LAS would be $8.4 \mathrm{~mm}(0.33 \mathrm{in}$.$) . The layer thickness is$ substantially larger than the thickness of original material consumed. For example, the calculated thickness of $\mathrm{SiC}$ consumed and thickness of the $\mathrm{SiO}_{2}$ layer on $\mathrm{SA}$ are about 1.8 and $3.6 \mu \mathrm{m}$, respectively, based on a weight change of $2.5 \mathrm{mg}$ and the theoretical densities of $\mathrm{SiC}$ and $\mathrm{SiO}_{2}$, but the actual layer thickness was about $25 \mu \mathrm{m}$. Evolution of $\mathrm{CO}$ during reaction and formation of bubbles of this gas in the layer might be the reason for this discrepancy. Additional insight into the nature of the surface layers can be obtained from the scanning electron microscope photographs in Figs. 9 through 11. Fracture surfaces of SA and RBSC after an exposure of $2000 \mathrm{~h}$ in Fig. 9 reveal an irregular interface between the layer and the parent material. Porosity is evident at the interface and isolated porosity occurs within the layers. Otherwise, the layers appear to be quite dense. The appearance of CSP was similar to that of SA and RBSC. X-ray diffraction revealed only one new compound, tridymite, in the layers on SA, CSP, and RBSC. Tridymite is a high-temperature, crystalline form of silica $\left(\mathrm{SiO}_{2}\right)$. The presence of $\mathrm{SiC}$ in the diffraction patterns for the three materiais was attributed to penetration of the X-ray beam through the surface layer to the underlying parent material.

Fracture surfaces of the LAS in Fig. 10 show gradual growth of the surface layer with increasing time of exposure. Porosity is evident both wit' in the layer and the adjacent parent material. Thickening of the layer would minimize release of residual Al. The weight change data for LAS in Figs. 3 and 4 show that weight loss, presumably caused by loss of $\mathrm{Al}$, occurred during the first $100 \mathrm{~h}$ of exposure; thereafter, the material gained weight because of thickening of the surface layer.

The morphology of the surface layer on the LAS is shown in Fig. 11. The original surface, which consisted of a mixture of phases, appears to consist of a rough glass containing needle-like crystals after an exposure of $100 \mathrm{~h}$. Substantial crystal growth, which is evident after 500 and $2000 \mathrm{~h}$, produced very irregular surfaces. The layer contained $\mathrm{Al}_{2} \mathrm{O}_{3}$, mullite $\left(3 \mathrm{Al}_{2} \mathrm{O}_{3} \cdot 2 \mathrm{SiO}_{2}\right)$, and cordierite $\left(2 \mathrm{MgO} \cdot 2 \mathrm{Al}_{2} \mathrm{O}_{3} \cdot 5 \mathrm{SiO}_{2}\right)$. Formation of cordierite was possible because the LAS contained a small amount of $\mathrm{MgO}$ as an impurity or fabrication aid. Comparison of the composition of the layer after $2000 \mathrm{~h}$ with that of the layer after $500 \mathrm{~h}$ indicated that the amount of mullite had decreased and that the amount of cordierite had 


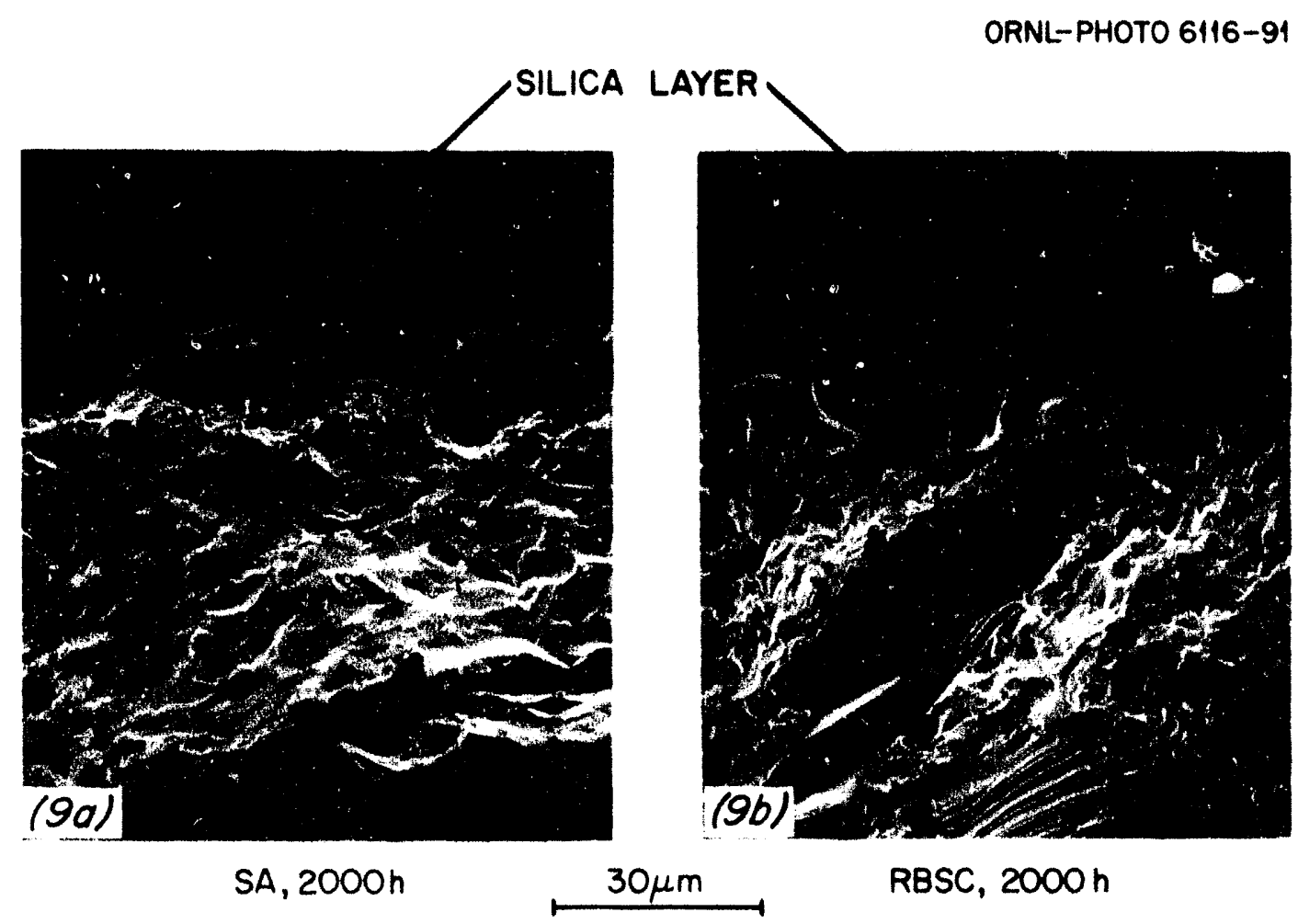

Fig. 9. Scanning electron microscope photographs of fracture surfaces of materials corroded for $2000 \mathrm{~h}$ : (a) SA and (b) RBSC210. 
5
1
$\vdots$
5
0
$\frac{0}{0}$
$\frac{1}{0}$
$\frac{1}{1}$
$\sum_{0}^{0}$

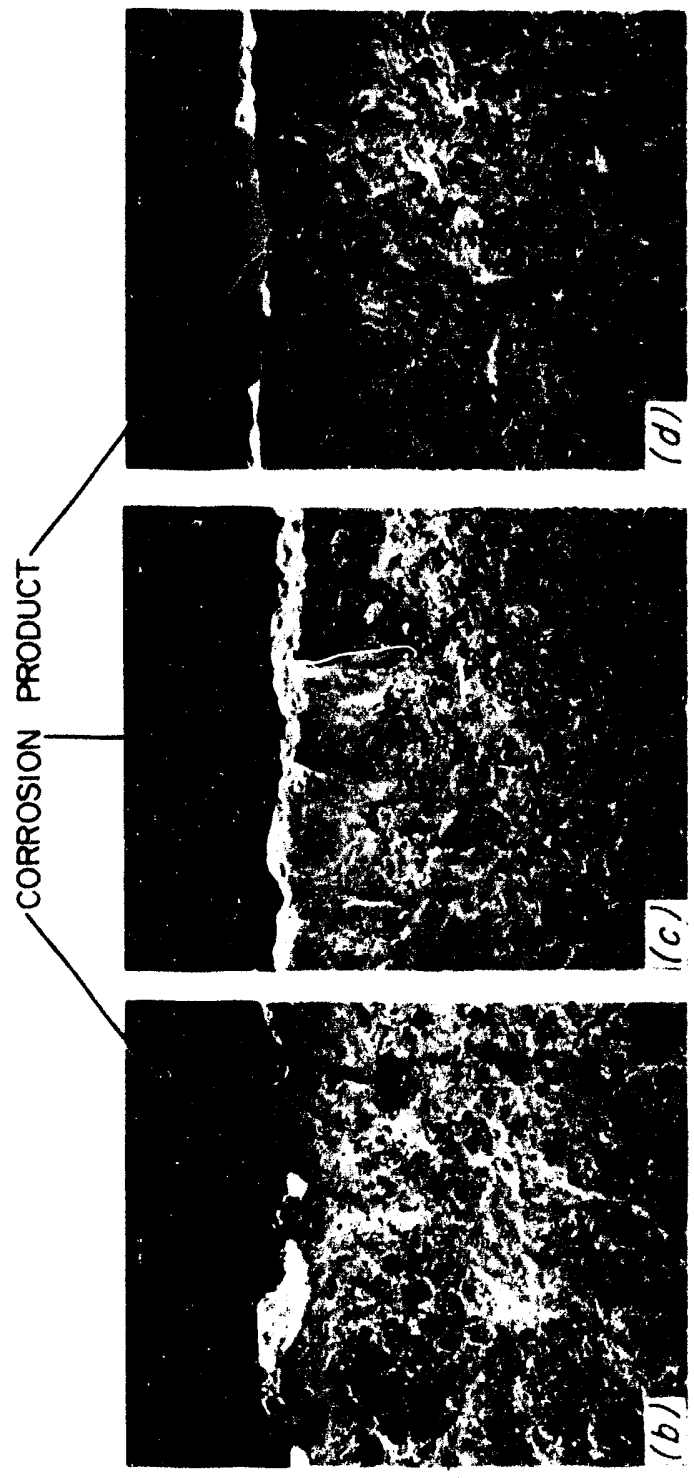

ㅇํㅇ

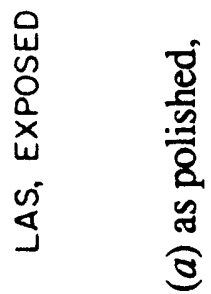

它

ह

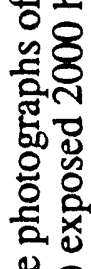

岗

ํㅐㅇㅠ

g

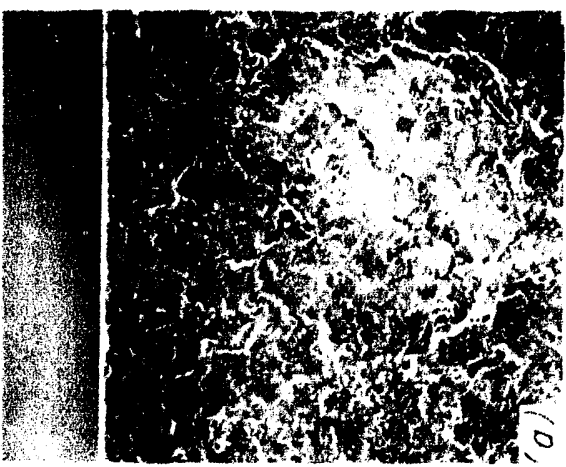

$\frac{1}{I}$
$\frac{1}{3}$
8
8
4
4
0
4

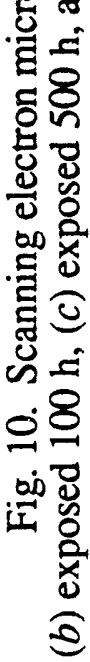




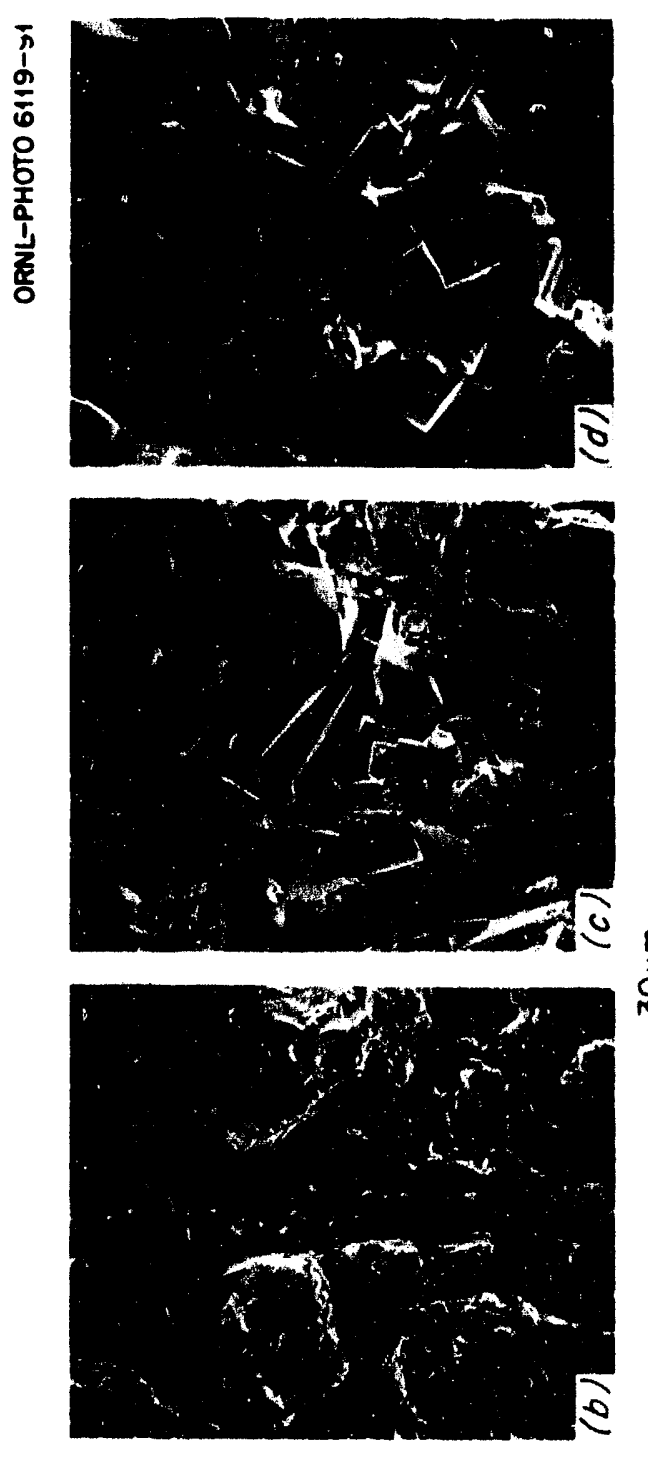

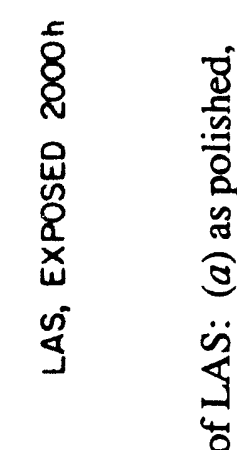

8

동

\&

क

苟

ज़

言

8 잉

응

岁

s)

药

ㄷㅇㅇ

氖

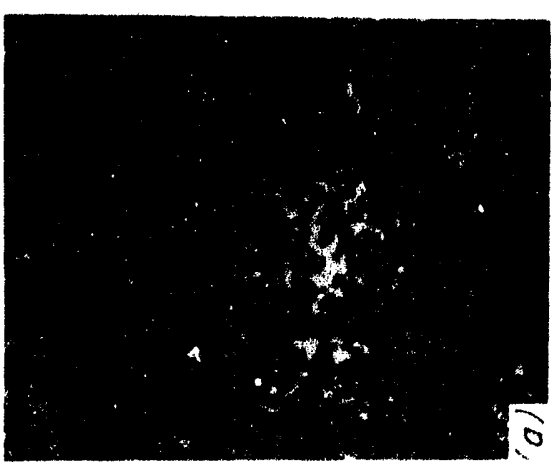

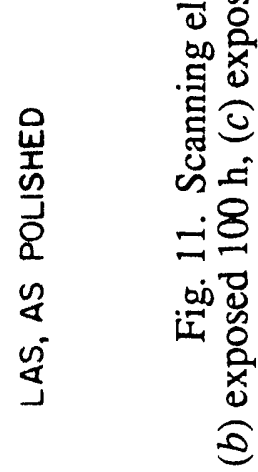


increased. Although the composition of the layer on the CAS was not investigated, Fig. 8 clearly shows that the layer was similar to that on the LAS (i.e., crystalline and rough on the outer surface).

Thus, as a result of corrosion for $2000 \mathrm{~h}$, the materials SA, CSP, and RBSC formed simple silica layers. These layers were smooth on the exterior surface but were irregular at the interface and contained porosity. The LAS material, however, formed a crystalline layer that was quite rough on the exterior surface and contained considerable porosity. The nature of these surface layers probably influenced the flexure strengths of these materials.

\subsection{FLEXURE STRENGTH}

The results of flexure testing are summarized in Table 4 and in Fig. 12. Corrosion testing of CHP, SNSC, ST, and CAS was stopped after only $500 \mathrm{~h}$ because the manufacturers indicated that these materials probably would not be available in the form of tubes of the required size within the time frame of this project. In addition, CHP and SNSC had relatively low flexure strengths (Fig. 12). The other four materials (i.e., SA, CSP, RBSC, and LAS)

Table 4. Flexure strengths and standard deviations of materials

\begin{tabular}{|c|c|c|c|c|c|c|c|c|}
\hline \multirow{3}{*}{ Material } & \multicolumn{8}{|c|}{ Average flexure strength, MPa (standard deviation)* } \\
\hline & \multicolumn{2}{|c|}{ As polished } & \multicolumn{2}{|c|}{ Exposed $100 \mathrm{~h}$} & \multicolumn{2}{|c|}{ Exposed $500 \mathrm{~h}$} & \multicolumn{2}{|c|}{ Exposed $2000 \mathrm{~h}$} \\
\hline & $20^{\circ} \mathrm{C}$ & $1260^{\circ} \mathrm{C}$ & $20^{\circ} \mathrm{C}$ & $1260^{\circ} \mathrm{C}$ & $20^{\circ} \mathrm{C}$ & $1260^{\circ} \mathrm{C}$ & $20^{\circ} \mathrm{C}$ & $1260^{\circ} \mathrm{C}$ \\
\hline SA & $342(36)$ & $391(32)$ & $267(39)$ & $\mathrm{ND}^{* *}$ & $334(33)$ & ND & $313(31)$ & $423(45)$ \\
\hline ST & $389(39)$ & ND & $397(47)$ & ND & $362(27)$ & ND & ND & ND \\
\hline CSP & $201(14)$ & $191(24)$ & $173(44)$ & ND & $227(36)$ & ND & $187(23)$ & $213(22)$ \\
\hline CHP & $106(14)$ & ND & $123(11)$ & ND & $140(14)$ & ND & ND & ND \\
\hline RBSC & $193(57)$ & 280 (19) & $238(23)$ & ND & $240(23)$ & ND & $257(33)$ & $351(19)$ \\
\hline SNSC & $75(5)$ & ND & $74(5)$ & ND & $67(8)$ & ND & ND & ND \\
\hline CAS & $554(70)$ & ND & $627(69)$ & ND & $495(92)$ & ND & ND & ND \\
\hline LAS & $463(51)$ & $218(37)$ & $197(20)$ & ND & $215(37)$ & ND & $177(39)$ & $186(23)$ \\
\hline
\end{tabular}

*Average of eight or ten specimens except fewer for SNSC.

${ }^{* *}$ ND - Not determined. 


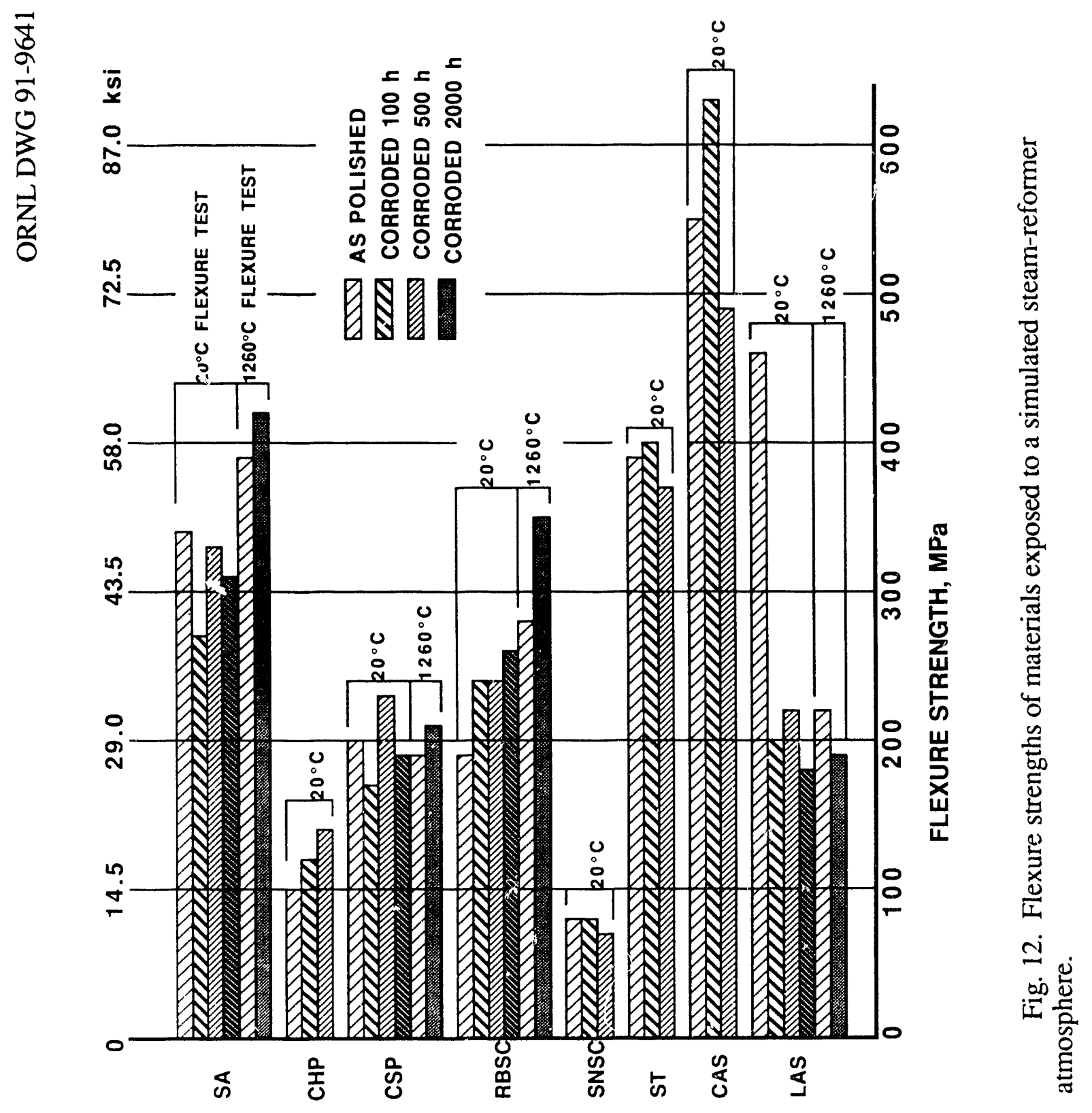


were tested for $2000 \mathrm{~h}$. In most cases, eight specimens of each material were broken in flexure to assess the effects of corrosion. A four-point loading fixture having 6.4- and 19.1-mm inner and outer spans, respectively, was used at a loading rate of about $4.6 \mathrm{~kg} / \mathrm{s}$. Specimens were broken at 20 and $1260^{\circ} \mathrm{C}$ in both the as-polished and corroded conditions. Specimens tested at $1260^{\circ} \mathrm{C}$ were heated to temperature in about $60 \mathrm{~min}$, held at temperature for about $30 \mathrm{~min}$, and then troken. Figure 12 shows that the strengths of exposed materials (except LAS) at either 20 or $1260^{\circ} \mathrm{C}$ were not greatly different from that of the unexposed, as-polished materials. The increases and decreases of exposed materials relative to the as-polished condition may be explained by the standard deviations associated with the average values in Table 4 . The strength of the LAS, however, was substantially less after corrosion. In addition, the LAS was substantially weaker in the as-polished condition at $1260^{\circ} \mathrm{C}$ compared with that at $20^{\circ} \mathrm{C}$.

\section{DISCUSSION}

Among the four materials corroded for $2000 \mathrm{~h}$, the behavior of the SiC ceramics differed from that of the LAS in terms of changes in weight and flexure strength and in the nature of the surface layer. The SiC ceramics gained weight by oxidizing to form a silica (i.e., tridymite) layer. The atmosphere (see Table 2) contained two oxidants, $\mathrm{H}_{2} \mathrm{O}$ and $\mathrm{CO}_{2}$, along with $\mathrm{H}_{2}$, $\mathrm{CO}$, and $\mathrm{CH}_{4}$. Another possible source of oxygen is the equilibrium concentration associated with $\mathrm{H}_{2}-\mathrm{H}_{2} \mathrm{O}$ and $\mathrm{CO}-\mathrm{CO}_{2}$ reactions. However, our calculations showed that the partial pressure of oxygen derived from these reactions at $1260^{\circ} \mathrm{C}$ is only about $10^{-10} \mathrm{~atm}$ or less. We conclude, therefore, that the $\mathrm{SiC}$ materials oxidized by reaction with $\mathrm{H}_{2} \mathrm{O}$ and $\mathrm{CO}_{2}$. Several possible reactions can be written to show formation of silica such as:

$$
\begin{aligned}
& \mathrm{SiC}+3 \mathrm{H}_{2} \mathrm{O}=\mathrm{SiO}_{2}+\mathrm{CO}+3 \mathrm{H}_{2}, \\
& \mathrm{SiC}+3 \mathrm{CO}_{2}=\mathrm{SiO}_{2}+4 \mathrm{CO},
\end{aligned}
$$

and

$$
\mathrm{SiC}+\mathrm{CO}_{2}+2 \mathrm{H}_{2} \mathrm{O}=\mathrm{SiO}_{2}+2 \mathrm{CO}+2 \mathrm{H}_{2}
$$

Although thermodynamically possible, these reactions reçuire diffusion of $\mathrm{H}_{2} \mathrm{O}$ or $\mathrm{CO}_{2}$ through the growing silica layer to the interface with $\mathrm{SiC}$ and might involve formation of intermediate compounds such as $\mathrm{SiO}, \mathrm{CH}_{2}, \mathrm{CH}_{4}$, etc. The fact that the weight increases did not always follow the parabolic relationship $x^{2}=k t$ (Fig. 4) suggests that diffusion of several species is involved. These reactions also produce compounds already present in the 
atmosphere, particularly $\mathrm{H}_{2}$ and $\mathrm{CO}$. However, the exposure test was conducted in flowing gases; thus, newly formed $\mathrm{H}_{2}, \mathrm{CH}_{4}$, and $\mathrm{CO}$ would be swept from the reaction site and their partial pressures would remain approximately constant. The formation of silica layers on SiC exposed to steam and to air containing $\mathrm{H}_{2} \mathrm{O}$ vapor has been previously studied..$^{7-9}$ Jorgensen et al. ${ }^{7}$ studied the oxidation of $\mathrm{SiC}$ powder in $\mathrm{Ar}-\mathrm{H}_{2} \mathrm{O}$ at 1 atm where the concentration ratio of $\mathrm{H}_{2} \mathrm{O}$ to Ar ranged from 0 to 0.0024 . At temperatures of 1218 to $1514^{\circ} \mathrm{C}$, they found that the oxidation rate depended on the $\mathrm{H}_{2} \mathrm{O}$ partial pressure, the oxidation product was either tridymite or cristobalite, and the diffusing species (although not determined) were probably the same in either the $\mathrm{Ar}-\mathrm{H}_{2} \mathrm{O}$ atmospheres or an $\mathrm{Ar}-\mathrm{O}_{2}$ atmosphere. Suzuki ${ }^{8}$ and Yoshimura et al. ${ }^{9}$ oxidized $\mathrm{SiC}$ powder at 400 to $800^{\circ} \mathrm{C}$ in steam at 10 and $100 \mathrm{MPa}$ (about 100 and $1000 \mathrm{~atm}$ ). At the higher pressure, oxidation increased with temperature from 0 at $400^{\circ} \mathrm{C}$. Amorphous silica formed at $500^{\circ} \mathrm{C}$, but cristobalite and tridymite crystallized above $7(0)^{\circ} \mathrm{C}$ after only a few hours. Reactions at the lower pressure were similar but slower. These authors postulated several possible reactions to explain their results:

$$
\begin{gathered}
\mathrm{SiC}+4 \mathrm{H}_{2} \mathrm{O}=\mathrm{SiO}_{2}+\mathrm{CO}_{2}+4 \mathrm{H}_{2}, \\
4 \mathrm{H}_{2}+2 \mathrm{O}_{2}=4 \mathrm{H}_{2} \mathrm{O}
\end{gathered}
$$

or

$$
\begin{aligned}
& \mathrm{SiC}+2 \mathrm{H}_{2} \mathrm{O}=\mathrm{SiO}_{2}+\mathrm{CH}_{4}, \\
& \mathrm{CH}_{4}+2 \mathrm{O}_{2}=\mathrm{CO}_{2}+2 \mathrm{H}_{2} \mathrm{O} .
\end{aligned}
$$

The first two reactions are thermodynamically favored at higher temperatures. They further postulated that since $\mathrm{H}_{2} \mathrm{O}$ diffuses faster than $\mathrm{O}_{2}$ in silica, the combined reactions are responsible for faster oxidation in steam than in air, although the final products are the same. Although the cxact reaction mechanism responsible for the resuits described in this report cannot be specified, we are confident that the atmosphere was oxidizing to $\mathrm{SiC}$ and that silica was the condensed product.

The specific volumes of tridymite and $\mathrm{SiC}$ are about 0.44 and $0.31 \mathrm{~cm}^{3} / \mathrm{g}$, respectively; thus, some disruption of the silica layer during growth could be expected. Figure 9 shows that the interface between the silica layer and the SiC ceramics is irregular and contains considerable porosity, an indication of the misfit that occurred when silica formed from the parent $\mathrm{SiC}$. The temperature of $1260^{\circ} \mathrm{C}$, however, apparently was high enough for surface diffusion to produce a relatively smooth outer surface, also evident in Fig. 9. 
Reaction of the atmosphere with the LAS was more complex. Initially, the SiC particles probably oxidized (at least partially) to $\mathrm{SiO}_{2}$ in a manner similar to the oxidation behavior of $\mathrm{SiC}$ ceramics. The $\mathrm{SiO}_{2}$ then reacted with the $\mathrm{Al}_{2} \mathrm{O}_{3}$ matrix and with $\mathrm{MgO}$, a minor constituent of the matrix, to form mullite $\left(3 \mathrm{Al}_{2} \mathrm{O}_{3} \cdot 2 \mathrm{SiO}_{2}\right)$ and cordierite $\left(2 \mathrm{MgO} \cdot 2 \mathrm{Al}_{2} \mathrm{O}_{3} \cdot 5 \mathrm{SiO}_{2}\right)$. The crystalline nature and associated porosity of the layer (Fig. 11) probably provided numerous paths for the oxidants to reach the $\mathrm{SiC}$; this resulted in a thicker layer than occurred on the SiC ceramics.

The retention of flexure strength of the SiC ceramics is attributed to the nature of the silica layer on the surface. The relatively smooth outer surface of the silica layer apparently did not contain significantly more or larger flaws than the as-polished surface; thus, no loss in strength occurred. Conversely, the crystalline, highly flawed surface of the LAS provided numerous stress concentrations during flexure testing. Results obtained by Kim and Moorhead ${ }^{10}$ support these interpretations. They showed that weight change, flexural strength, and morphology of SA after exposure to $\mathrm{H}_{2}-\mathrm{H}_{2} \mathrm{O}$ mixtures at 1300 and $1400^{\circ} \mathrm{C}$ are strongly dependent on the partial pressure of water $\left(\mathrm{P}_{\mathrm{H}_{2}} \mathrm{O}\right)$ in the range $5 \times 10^{-6}$ to $5 \times 10^{-3} \mathrm{~atm}$. The strength was not affected at the lower value and was actually higher than that of as-received material at the higher value; however, at intermediate values of $\mathrm{P}_{\mathrm{H}_{2} \mathrm{O}}$, the strength was substantially decreased. The strength decrease was attributed to defects in the corrosion layer, and the strength increase was attributed to crack healing or blunting by formation of a silica layer, both morphologies being readily discernible by scanning electron microscopy. Kim and Moorhead ${ }^{11,12}$ also obtained results for Nicalon* $\mathrm{SiC}$ fibers and $\mathrm{Si}_{3} \mathrm{~N}_{4}$ showing that flexure strengths were highly dependent on the nature of the corroded surface.

Figure 12 shows that the strength of the LAS in the as-polished condition was lower at $1260^{\circ} \mathrm{C}$ than at $20^{\circ} \mathrm{C}$. Although the flexure test at $1260^{\circ} \mathrm{C}$ involved only about $1 \mathrm{~h}$ at temperature, we assume that migration of $\mathrm{Al}$ to the surface, followed by oxidation and reaction with silica, formed strength-limiting defects, but this phenomenon has not been thoroughly investigated.

Figure 12 also shows that the strength of the CAS increased after exposure for $100 \mathrm{~h}$ but decreased after $500 \mathrm{~h}$. This behavior was probably caused by the initial growth of a beneficial silica layer (which increased strength) followed by the formation of crystals within the thickening layer (which decreased strength).

\footnotetext{
*Nippon Carbon Company, Tokyo, Japan.
} 


\section{CONCLUSIONS}

The most important conclusions to be derived from these corrosion studies at $1260^{\circ} \mathrm{C}$ and 1 atm pressure are as follows:

1. The simulated steam-reformer atmosphere was oxidizing to $\mathrm{SiC}$ ceramics that gained weight by forming a silica layer.

2. The silica layer, being adherent and continuous, protected the SiC ceramics from catastrophic oxidation.

3. The silica layer did nct significantly affect the flexure strength (in air) of SiC ceramics at 20 or $1260^{\circ} \mathrm{C}$.

4. Oxide composites containing $\mathrm{SiC}$ as a strengthening and toughening agent were susceptible to oxidation in the steam-reformer atmosphere.

5. Oxidation of $\mathrm{SiC}$ in the composites was followed by reaction with the oxide matrix to form new crystalline phases.

6. The new crystalline phases and associated porosity that formed during oxidation decreased the strength of the composites.

\section{ACKNOWLEDGMENTS}

The authors express their appreciation to J. J. Williams and R. A. Rosenberg (SWEC) for providing the ceramic test materials and guidance for test conditions; to P. J. Jones (ORNL) for assembling corrosion test equipment, conducting the exposure tests, and performing flexure tests; to J. R. Mayotte for preparing optical micrographs; to O. B. Cavin for identifying phases by X-ray diffraction; to M. A. Karnitz for providing technical guidance; to D. P. Stinton and R. A. Lowden for performing a technical review; to H. R. Livesay for preparing figures; to K. Spence for editing; and to G. R. Carter for preparing the final version of this report.

\section{REFERENCES}

1. Development of a High Pressure Heat Exchange System (HiPHES) for Reforming of Methane, DOE/ID/12797-1, U.S. DOE, May 1990.

2. J. J. Williams, R. A. Rosenberg, and L. J. McDonough, "High Temperature Ceramic-Tubed Reformer," presented at the AIChE 1990) Spring National Meeting, Orlando, Fla., Mar. 22, 1990. 
3. B. Harkins and M. Ward, "High Pressure Heat Exchange Systems," Final Report for the Period October 1, 1988-September 30, 1989, DOE/ID/12799-1, U.S. DOE, Mar. 30, 1990.

4. Technology Assessment and Research and Development Needs, U.S. DOE, October 1987 (Assessment of High Pressure Heat Exchange Systems Technology, DOE/ID/12799-1, Vol. 1).

5. Appendices, U.S. DOE, October 1987 (Assessment of High Pressure Heat Exchange Systems Technology, DOE/CE/40716-2,Vol. 2).

6. O. Kubaschewski and B. E. Hopkins, Oxidation of Metals and Alloys, Butterworths, London, 1962, p. 35.

7. Paul J. Jorgensen, Milton E. Wadsworth, and Ivan B. Cutler, "Effects of Water Vapor on Oxidation of Silicon Carbide," J. Am. Ceram. Soc. 44(6), 258-61 (1961).

8. H. Suzuki, "Study of Oxidation of Silicon Carbide Powders: II, Effects of Steam on Oxidation of Silicon Carbide of Various Colors and Crystal Structures," Ceram. Abstr. $113 \mathrm{e}(1960)$.

9. Masahiro Yoshimura, Jun-ichiro Kase, and Shigeyuki Somiya, "Oxidation of SiC Powders by High-Temperature, High-Pressure $\mathrm{H}_{2} \mathrm{O}$," J. Mater. Res. 1(1) (Jan./Feb. 1986).

10. Hyoun-Ee Kim and Arthur J. Moorhead, "Effects of Hydrogen-Water Atmospheres on Corrosion and Flexural Strength of Sintered-Silicon Carbide," J. Am. Ceram. Soc. 73(3), 694-99 (1990).

11. Hyoun-Ee Kim and Arthur J. Moorhead, "Strength of Nicalon Silicon Carbide Fiber Exposed to High-Temperature Gaseous Environments," J. Am. Ceram. Soc. 74(3), 666-69 (1991).

12. Hyoun-Ee Kim and A. J. Moorhead, "High-Temperature Gaseous Corrosion of $\mathrm{Si}_{3} \mathrm{~N}_{4}$ in $\mathrm{H}_{2}-\mathrm{H}_{2} \mathrm{O}$ and $\mathrm{Ar}-\mathrm{O}_{2}$ Environments," J. Am. Ceram. Soc. 73(10), 3007-14 (1990). 
ORNL/TM-11828

\section{INTERNAL DISTRIBUTION}

1-2. Central Research Library

3. Document Reference Section

4-5. Laboratory Records Department

6. Laboratory Records, ORNL RC

7. ORNL Patent Section

8-10. M\&C Records Office

11. R. L. Beatty

12. P. F. Becher

13. G. C. Bell

14. T. M. Besmann

15. R. S. Carlsmith

16. P. T. Carlson

17. N. C. Cole

18. D. F. Craig

19. J. H. DeVan

20-24. J. I. Federer

25. E. L. Fuller, Jr.

26. W. A. Gabbard

27. L. L. Horton

28. C. R. Hubbard

29. R. R. Judkins

30. M. J. Kania

31. J. R. Keiser
32-36. H. E. Kim

37. O. F. Kimball

38. E. L. Long, Jr.

39. R. A. Lowden

40. R. C. Martin

41. J. R. Mayotte

42-46. A. J. Moorhead

47. T. A. Nolan

48. O. O. Omatete

49. P. S. Sklad

50. G. M. Slaughter

51. D. P. Stinton

52. R. A. Strehlow

53. V. J. Tennery

54. T. N. Tiegs

55. J. R. Weir

56. D. F. Wilson

57. A. D. Brailsford (Consultant)

58. Y. A. Chang (Consultant)

59. H. W. Foglesong (Consultant)

60. J. J. Hren (Consultant)

61. M. L. Savitz (Consultant)

62. J. B. Wachtman, Jr. (Consultant)

\section{EXTERNAL DISTRIBUTION}

63. AIRESEARCH MANUFACTURING COMPANY, 2525 W. 190th Street, Torrance, CA 90509

D. M. Kotchick

64. AMERCOM, 8928 Fullbright Avenue, Chatsworth, CA 91311

W. E. Beyerrnann

65. BABCOCK AND WILCOX, R\&D Division, 1562 Beeson Street, Alliance, $\mathrm{OH} 44601$

C. L. DeBellis

66-67. BABCOCK AND WILCOX, P.O. Box 11165, Lynchburg, VA 24505

E. A. Barringer

D. L. Hindman 
68-69. CARBORUNDUM COMPANY, P.O. Box 337, 1625 Buffalo Ave., Niagara Falls, NY 14302

C. Ebel

R. Storm

70. CARBORUNDUM COMPANY, P.O. Box 1054, Niagara Falls, NY 14302

M. C. Kerr

71. CONSOLIDATED NATURAL GAS, 11001 Cedar Avenue, Cleveland, OH 44106

J. Bjerklie

72. COORS CERAMICS CO., 17750 West 32 Ave., Golden CO 80401

J. Sibold

73. COORS PORCELAIN COMPANY, 600 Ninth Street, Golden, CO 80501

R. Kleiner

74. DOW CORNING CORPORATION, 3901 South Saginaw Road, Midland, MI 48640

W. H. Atwell

75. DREXEL UNIVERSITY, Building 27-439, Philadelphia, PA 19104

F. Ko

76-78. GAS RESEARCH INSTITUTE, 860() W. Bryn Mawr Ave., Chicago, IL 60631

S. Freedman

M. A. Lukasiewicz

C. Stala

79. GENERAL ELECTRIC COMPANY, GE Corporate Research and Development,

11120 S. Norwalk Blvd., Sante Fe Springs, CA 90670

J. A. Mears

8()-81. GENERAL ELECTRIC COMPANY, GE Corporate Research and Development,

P.O. Box 8, Schenectady, NY 12301

H. W. Lake, Bldg. KW, Rm. C258

F. N. Mazandarany, Bldg. K-1, MB-259

82. GENERAL MOTORS CORPORATION, Allison Gas Turbine Division,

BF Goodrich, Aerospace, P.O. Box 420, Indianapolis, IN 46206-()420

C. Wilkes 
83. IDAHO NATIONAL ENGINEERING LABORATORY, P.O. Box 1625, Idaho Falls, ID 83415

B. W. Brown

84. MASSACHUSETTS INSTITUTE OF TECHNOLOGY, 77 Mass. Ave., Rm. 12-009, Cambridge, MA 02139

\section{J. S. Haggerty}

85-86. NORTON COMPANY, 1 New Bond Street, Worcester, MA 01606

B. D. Foster

K. Green

87. PAR ENTERPRISE, INC., 12601 Clifton Hunt Lane, Clifton, VA 22024

W. J. Rebello

88. PENNSYLVANIA STATE UNIVERSITY, 227 Hammond Building, University Park, PA 16802

H. T. Hahn

89. PENNSYLVANIA STATE UNIVERSITY, 408 Walker Building, University Park, PA 16802

J. R. Hellmann

90. POWER GENERATION CONSULTANTS, 1261 Post House Lane, Media, PA 19063

M. DeCorso

91-92. REFRACTORY COMPOSITES, INC., 12220-A Rivera Rd., Whittier, CA 90606

K. Kratsch

E. L. Paquette

93-94. SOLAR TURBINES INCORPORATED, P.O. BOX 85376, San Diego,

CA $92138-5376$

B. Harkins

M. Van Roode

95-97. STONE \& WEBSTER ENGINEERING CORPORATION, 245 Summer Street, Boston, MA 02107

L. J. McDonough

R. A. Rosenberg

J. J. Williams 
98. SULLIVAN MINING CORPORATION, P.O.Box 4615, San Diego, CA 92121

T. M. Sullivan

99. TEXTRON, INC., 2 Industrial Ave., Lowell, MA 01851

B. N. Thompson

100. UNIVERSITY OF ILLINOIS AT CHICAGO, P.O. Box 4348, Chicage, IL 60680

M. J. McNallan

101. UNIVERSITY OF TENNESSEE SPACE INSTITUTE, MS 3, Tullahoma, TN 37388

W. H. Boss

102-103. U.S. DOE, CHICAGO FIELD OFFICE, 9800 S. Cass Avenue, Argonne, IL 60439

J. E. Jonkouski

J. Mavec

104. U.S. DOE, DIVISION OF WASTE ENERGY REDUCTION, 1000 Independence Ave., S.W., Washington, DC 20585

J. N. Eustis

105. U.S. DOE, IDAHO OPERATIONS OFFICE, 550 Second Street, Idaho Falls, ID 83401

G. R. Peterson

106-1 14. U.S. DOE, MORGANTOWN ENERGY TECHNOLOGY CENTER, P.O. Box 880, Morgantown, WV 26505
R. A. Bajura
R. C. Bedick
D. C. Cicero
F. W. Crouse, Jr.
N. T. Holcombe

W. J. Huber

M. J. Mayfield

J. E. Notestein

J. S. Wilson

115. U.S. DOE, OFFICE OF BASIC ENERGY SCIENCES, Materials Sciences Division, ER-131 GTN, Washington, DC 20545

J. B. Darby

116. U.S. DOE, OFFICE OF CONSERVATION AND RENEWABLE ENERGY, CE-12 Forrestal Building, Washington, DC 20545

J. J. Eberhardt 
117-119. U.S. DOE, OFFICE OF FOSSIL ENERGY, Washington, DC 20545

D. J. Beecy (FE-14) GTN

J. P. Carr (FE-14) GTN

F. M. Glaser (FE-14) GTN

120-122. U.S. DOE, OFFICE OF INDUSTRIAL TECHNOLOGIES, 1000 Independence Avenue, Forrestal Building, Washington, DC 20585

J. Eustis

W. P. Parks, Jr.

S. L. Richlen

123-126. U.S. DOE, PITTSBURGH ENERGY TECHNOLOGY CENTER, P.O. Box 10940, Pittsburgh, PA 15236
A. H. Baldwin
G. V. McGurl
R. Santore
T. M. Torkos

127-128. U.S. DOE, OAK RIDGE FIELD OFFICE, P.O. Box 2001, Oak Ridge, TN 37831-8600

M. J. Rohr

Assistant Manager for Energy Research and Development

129. U.S. DOE, OAK RIDGE FIELD OFFICE, Oak Ridge National Laboratory, P.O. Box 2008, Oak Ridge, TN 37831-6269

E. E. Hoffman

130-139. U.S. DOE, OFFICE OF SCIENTIFIC AND TECHNICAL INFORMATION, P.O. Box 62, Oak Ridge, TN 37831

For distribution by microfiche as shown in DOE/OSTI-4500,

Distribution Category UC-310 [Industrial Programs (General)] 

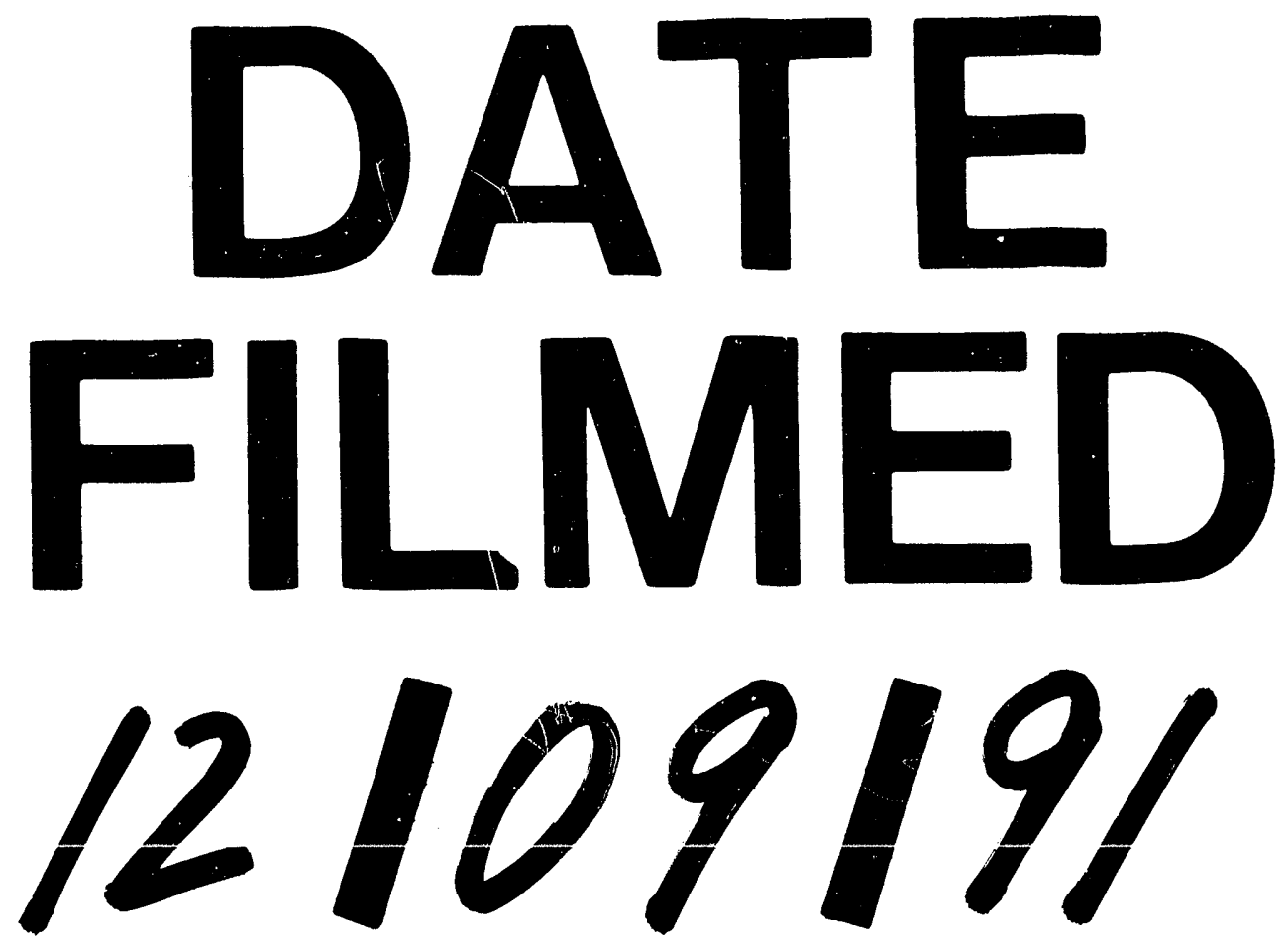
